\title{
A EXCLUSÃO SOCIAL E AS FAVELAS NA CIDADE DO RIO DE JANEIRO
}

\author{
SOCIAL EXCLUSION AND SLUM IN RIO DE JANEIRO
}

\section{Marconi do Ó Catão ${ }^{1}$}

\section{Resumo}

Este texto discorre sobre as iniquidades sociais presentes na realidade do cotidiano brasileiro, como consequências advindas da Globalização. O objetivo central deste estudo é articular as concepções de pobreza e exclusão social, com o paradoxo da cidade do Rio de Janeiro, como reflexo das desigualdades sociais ainda presentes no século XXI. O método de procedimento adotado foi o descritivo-analítico, no intuito de realizar uma abordagem entre as áreas jurídica, social e urbanística. Assim, apresentamos um problema resultante dos históricos modelos urbanos adotados no Brasil, cujo planejamento insuficiente acarreta sérias repercussões nos campos sanitário, ambiental, econômico e, especialmente, social. Os estudos realizados permitiram concluir que um número significativo de moradores das favelas do Rio de Janeiro integram grupos sociais caracterizados pela exclusão, pobreza e privação ou ineficácia no atendimento dos direitos sociais. Por fim, foi evidenciada a necessidade de políticas públicas urbanas que solucionem a problemática do direito à moradia digna, por intermédio da efetivação de programas de regularização fundiária no Brasil.

Palavras-chave: Exclusão Social; Regularização das Favelas; Rio de Janeiro/Cidade.

\section{Abstract}

This paper discusses the social inequities present in the reality of Brazilian daily life, as the consequences resulting from globalization. The central aim of this study is to articulate the concepts of poverty and social exclusion, with the paradox of the city of Rio de Janeiro as a reflection of social inequalities still present in the XXI century. The method of procedure adopted was descriptiveanalytical, in order to implement an approach between the legal, social and urban areas. Thus, we present a resulting problem of historical urban development models adopted in Brazil, whose lack of planning has serious repercussions in the health, environmental, economic and especially social fields. The studies showed that the vast majority of slum dwellers in Rio de Janeiro integrate social groups characterized by exclusion, poverty and deprivation or ineffectiveness in the care of social rights. Finally, we showed the need of urban public policies that address the issue of the right to adequate housing, through the realization of suitable land regularization programs in Brazil.

Keywords: Social Exclusion; Regularization of Slum; City of Rio de Janeiro.

\footnotetext{
${ }^{1}$ Doutorando em Direito da Cidade, pela Universidade Estadual do Rio de Janeiro; Doutor em Sociologia, pela Universidade Federal da Paraíba; Mestre em Direito, pela Universidade Federal do Ceará; Professor do Departamento de Direito Privado do Centro de Ciências Jurídicas da Universidade Estadual da Paraíba. E-mail: moct@uol.com.br
} 


\section{INTRODUÇÃO}

Em todo o mundo, a perspectiva de internacionalização da economia, juntamente com a tendência neoliberal, desencadearam uma elevação significativa das desigualdades sociais. Logo, a temática da justiça social tornou-se o foco das discussões locais e internacionais, tendo em vista que o aumento das desigualdades e, consequentemente, da exclusão social, surgiram como fatores determinantes de rupturas sociais, afastando então o ideal de concretização de uma nova sociedade, democrática e justa.

Nesse sentido, a problemática da injustiça social, concomitantemente ao fenômeno da construção de um modelo social moderno, isso entre os séculos XVI e XVIII, são matérias de constantes estudos e debates entre os intelectuais deste período. Na Europa, o século XIX ficou caracterizado pelas discussões sobre as iniquidades sociais a partir da Revolução Industrial; já na América Latina, tal abordagem eclodiu, sobretudo, com as independências das colônias e com a abolição da escravatura. No Brasil, esse assunto tem igualmente toda uma história, representando um dos alicerces fundantes de nossa identidade e pensamento social, que, lamentavelmente, resultaram na atual realidade social revelada na figura concreta da exclusão.

Na conjuntura nacional brasileira, é comum haver uma certa associação, com tendência a homogeneização, entre os temas basilares das iniquidades sociais, representadas pela desigualdade, pobreza e exclusão. Assim, torna-se pertinente, inicialmente, fazermos uma breve distinção conceitual entre eles: a desigualdade social diz respeito à distribuição diferenciada (para mais ou para menos) das riquezas materiais e simbólicas produzidas por uma sociedade e apropriadas pelos seus participantes; a pobreza, por sua vez, traduz a situação em que se encontram os membros de um determinado grupo de pessoas sem recursos adequados para ter uma vida digna, ou que não dispõem de condições mínimas para manter suas necessidades humanas mais elementares; já a concepção de exclusão social se aproxima, em um contexto de oposição, ao conceito de coesão social ou, na perspectiva de ruptura, com a ideia de vínculo social. Acrescente-se, também, no sentido de similitude, a identificação da exclusão social com as noções de desvio e de estigma; sendo que neste caso, a diferença se verifica no fato de que o excluído não precisa praticar nenhuma transgressão, de modo diverso do desviante e a semelhança dos que sofrem discriminação pura e simples. ${ }^{2}$

No século passado, a partir da década de 1980, houve uma significativa ampliação do processo de internacionalização das economias capitalistas que se convencionou chamar de Globalização, sendo caracterizado por uma integração dos mercados financeiros mundiais e por um crescimento do

\footnotetext{
${ }^{2}$ NASCIMENTO, Elimar Pinheiro do. Dos excluídos necessários aos excluídos desnecessários. In. BURSZTYN. No meio da rua: nômades, excluídos e viradores. 2. ed. Rio de Janeiro: Garamond, 2003, p. 58-59.
} 
comércio internacional, especialmente no âmbito dos grandes blocos econômicos. Nesse cenário, ressalte-se a presença crescente de empresas transnacionais, representando um aspecto peculiar, pois, diversamente das corporações multinacionais, características nas décadas de 60 e 70 do século XX, constituem uma nova realidade no âmbito mercadológico.

Desse modo, as decisões internacionais exteriorizam-se por uma ampla movimentação financeira, que têm lógicas autônomas em relação aos Estados Nacionais. Em consequência disso, o espaço para operacionalização de políticas públicas vê-se bastante reduzido, visto que a condução das iniciativas sociais financeiras é comprometida pela imensa quantidade de recursos que circula no mercado econômico internacional, ultrapassando as fronteiras nacionais.

Nessa ótica, convém perceber que, ao contrário das empresas multinacionais, com tendência a reprodução das tradicionais relações de trabalho, as empresas transnacionais, além de fabricarem diferentes partes do produto em vários países, os realizam sob contratos de trabalho diversificados, optando pela conveniência adequada ao caso especifico (mão de obra familiar, contratos convencionais, trabalho em tempo parcial, parcerias etc.). Dessa forma, o atual padrão de acumulação de capital vem modificar a tradicional noção de ocupação, haja vista que formou uma nova concepção de emprego, sendo mais flexível, precário e sem as garantias de estabilidade típicas do padrão convencional.

Portanto, em sociedades nas quais o emprego traduz um referencial, tanto na obtenção de renda quanto nos processos de integração social e de formação da identidade pessoal, tal transformação tem um impacto significativo, levando ao surgimento de uma representação social a partir do sentimento de desamparo, que é maximizada pelo fato de o Estado, que antes da Segunda Grande Guerra era tido como garantidor das proteções sociais, encontrar-se passando por uma reestruturação, redefinindo suas funções.

Com efeito, Wolfe ${ }^{3}$ enfatiza o fato de que os trabalhadores que anteriormente tinham acesso a bens públicos e benefícios sociais garantidos pelo Estado, incorporando-os às suas expectativas, viram-se ameaçados nestes direitos, gerando assim uma consciência de injustiça e agravamento das condições de vida. Logo, foi neste contexto globalizado e de modificação na função estatal que eclodiu uma nova variedade de exclusão social.

De fato, em várias cidades do Brasil, áreas centrais modernas encontram-se praticamente cercadas por parcelamentos periféricos pobres, em geral irregulares, sendo a autoconstrução uma constante. De maneira que, nos setores mais valorizados, edifícios e construções luxuosas coexistem

\footnotetext{
3 WOLFE, Marshall. Globalization and social exclusion: some paradoxes. In: ROGERS, Gary; GORE, Charles \& FIGUEIREDO, José (Orgs). Social exclusion: rethorie, reality, reposnes. Genebra: International Institute for Labor Studies, 1995. Passim.
} 
com favelas, que geralmente resultam de invasões de terrenos públicos e/ou privados; por conseguinte, tanto a prestação de serviços públicos quanto a distribuição de equipamentos de consumo coletivo são bastante desiguais, com as áreas mais pobres apresentando precários sistemas de drenagem e saneamento básico, reduzidos aparatos de saúde e educação, limitadas áreas de lazer etc.

Em geral, as cidades ${ }^{4}$ têm favorecido o progresso do conhecimento, da cultura e dos costumes, pois é o lugar onde ocorrem as transformações econômicas e sociais da sociedade contemporânea. Contudo, o início deste século tem revelado a permanência de inúmeros problemas urbanos, tais como degradação do meio ambiente; restritas oportunidades de emprego e obtenção de renda; elevação da violência urbana; crescimento da pobreza; ausência de moradia digna; inadequação do suprimento da água e de saneamento básico; entre outros.

Então, tendo como marco referencial a Constituição Federal de 1988 (CF/88), seguindo-se pelo Estatuto da Cidade (Lei n. 10.257, de 10.06.2001) pelas respectivas legislações municipais (Lei Orgânica do Município e Plano Diretor) e demais leis correlatas, o Município tem, entre outras atribuições, a função de legislar sobre a estruturação e ordenação do espaço urbano, por meio de: zoneamento ${ }^{5}$, loteamento, controle de construções, paisagismo, uso e ocupação do solo, código de posturas - em suma, tais instrumentos devem conter diretrizes das mais diversas, desde as relacionadas às condições de acesso dos cidadãos aos seus direitos fundamentais (emprego, habitação, serviços de água e saneamento básico, entre outros); perpassando pela proteção ao meio ambiente e patrimônio natural, incluindo, também, aqueles direitos relacionados com o respeito aos aspectos sociais e econômicos.

De forma que este texto se propõe, inicialmente, a fazer uma breve exposição sobre as concepções relacionadas com a desigualdade social, pobreza e exclusão, para então chegar a temática da questão urbanística brasileira. Logo, a princípio, será realizado um estudo sobre as consequências advindas das clássicas iniquidades sociais, ainda presentes na grande maioria das cidades brasileiras,

4 Com relação às dimensões histórica e cultural das cidades, levando-se em consideração suas origens e transformações, remetemos o leitor aos emblemáticos trabalhos de Mumford. Cf. MUMFORD, L. A cidade na história: suas origens, transformações e perspectivas. Trad. Neil R. da Silva. 5 ed. São Paulo: Martins Fontes, 2008.;

A cultura das cidades. Trad. Neil R. da Silva. Belo Horizonte: Itatiaia, 1961; v.tb. CATÃO, M.. Civilizações urbanas e teorias da cidade / Urban civilizations and city theories. Revista de Direito da Cidade, Rio de Janeiro, 7, fev. 2015. Disponível em: http://www.e-publicacoes.uerj.br/index.php/rdc/article/view/15201. Acesso em: 15 Abr. 2015.

5 Sobre esta perspectiva, encontramos um estudo que tem como característica fundamental o acompanhamento das linhas arquitetônicas de Le Corbusier, desenvolvido por Dantas, onde discute o urbanismo moderno por meio do zoning, ou seja, a separação da cidade em zonas de usos distintos de habitação, comércio, lazer e circulação. Cf. DANTAS, M. G. A. Planejamento Urbano \& Zoning: flexibilidade do modelo de zoning para a competitividade das cidades. João Pessoa: UFPB, 2003; v.tb. GOUVÊA, L.A. Biocidade: .... São Paulo: Nobel, 2002. 
objetivando demonstrar que as transformações econômicas decorrentes da modernidade globalizada sempre reproduziram a difícil inserção do pobre na produção, no consumo e na cidadania. Ademais, este estudo também tem como meta desenvolver uma abordagem no que diz respeito ao paradoxo das favelas da cidade do Rio de Janeiro, como reflexo das desigualdades sociais que continuam presentes neste início de século.

Nesse contexto, ressalte-se que a discussão a ser realizada pretende articular os campos jurídico, sociológico e urbanístico, sendo que, para isso, utilizaremos uma metodologia descritivoanalítica, por meio da realização de levantamentos bibliográficos e documentais, relacionando a temática da regularização fundiária das favelas, a partir da cidade do Rio de Janeiro, com as perspectivas da exclusão social, pobreza e desigualdade. De maneira que tais aspectos serão discutidos no âmbito das questões concernentes aos direitos sociais, ao direito à igualdade e aos direitos de cidadania, sempre procurando um embasamento por meio das legislações brasileiras que tratam do processo de regularização fundiária das favelas nos planejamentos urbanos das cidades.

Zygmunt Bauman ${ }^{6}$ adverte que a produção do "refugo humano" é consequência direta da modernização da sociedade e da globalização da economia. De acordo com este autor, pobres, pessoas em busca de moradia e desempregados são apenas a parcela mais visível deste grupo de seres humanos redundantes, dispensáveis, consumidores falhos, "sem-teto sociais", excluídos da cena pública, inaptos para participação na sociedade de consumo e, por isso mesmo, irrelevantes com relação às tomadas de decisões e deliberações de políticas públicas. Continuando, salienta Bauman que: "[...] removemos os dejetos de maneira mais radical e efetiva: tornando-os invisíveis, por não olhá-los, e inimagináveis, por não pensarmos neles". Nessa mesma perspectiva, o "Mapa da Injustiça Ambiental e Saúde no Brasil"7 indica a existência de determinados grupos sociais que são vulneráveis aos processos políticos, econômicos e culturais, geradores de discriminações e desigualdades relacionadas à distribuição de ônus e bônus da modernidade.

Em síntese, é essa realidade que justifica o desenvolvimento deste texto, pois os moradores de favelas, em sua grande maioria, são pessoas que não tiveram oportunidades de adquirir sua casa própria. Então, sem alternativas viáveis, eles procuram fixar-se em localidades próximas às cidades; sendo que, muitas vezes, encontram áreas ambientalmente degradadas, que surgem como única forma de habitação possível.

\footnotetext{
${ }^{6}$ BAUMAN, Zygmunt. Vidas desperdiçadas. Rio de Janeiro: Zahar, 2004.

7 BRASIL. Mapa de Injustiça Ambiental e Saúde no Brasil. 2010. Disponível em: http://www.conflitoambiental.icict.fiocruz.br. Acesso em: 2 abr.2011.
} 


\section{DA EXCLUSÃO SOCIAL À QUESTÃO URBANA}

Hodiernamente, a discussão sobre exclusão social se concentra na reestruturação produtiva, que se encontra presente não apenas em países em desenvolvimento, mas também nos desenvolvidos. Em sentido amplo, exclusão é um processo bastante antigo, pois seu conceito existe desde a Idade Média, quando se distinguia sob a forma, por exemplo, do ostracismo ateniense, do desterro romano, da condição de pária hindu, bem como do exílio e gueto existentes naquelas sociedades; sendo que, hoje em dia, ainda que tal concepção esteja vinculada à expulsão da esfera econômica, há muita celeuma sobre o tema, pois sua noção também é utilizada para descrever várias categorias de pessoas em situações social e econômica diversas, como a dos pobres, marginais, estrangeiros, enfim, dos estigmatizados.

A sociedade contemporânea tem seus valores voltados para o progresso e o trabalho, logo, as pessoas que não possuem capacidade ou possibilidade de participar do mercado de trabalho formal são vistas como excluídas. Nesta perspectiva, a pobreza surge como sinônimo da incapacidade de participar do mercado de consumo, enquanto que o desemprego aparece como a falta de capacidade de participar da atividade laboral, sendo esses elementos considerados desencadeadores de exclusão.

De um modo geral, para os dicionaristas ${ }^{8}$, o termo "exclusão" é definido com expressões que indicam separação, fração, ruptura, incompatibilidade etc. Mas, tal conceituação é questionável, pois por quem seria provocada? Contra quem? Na nossa compreensão, essa linha de pensamento diz respeito a um certo descompasso, de algo ou alguém que sai do padrão de normalidade esperado; ou, talvez, esse outro seja apenas diferente e, devido a isto, fuja ao modelo desejado, recebendo assim um rótulo. Desse modo, se há um excluído é porque também há um incluído, não sendo uma realidade que se impõe por si mesma, devendo tal fato ser analisado em um âmbito conjuntural ou em uma relação específica com algo.

Na compreensão de Tezanos ${ }^{9}$, a exclusão social inclui todas as pessoas que se encontram fora das oportunidades vitais que descrevem uma cidadania social plena, ou seja, - "en términos de aquello de lo que se carece, de lo que se queda fuera". Como vemos, é saliente a polaridade conceitual revelada por meio da noção de inclusão ou integração social; por conseguinte, é vislumbrada uma visão dicotômica da sociedade, onde de um lado estariam os integrados ou incluídos, e, do outro, os excluídos. Em outras palavras, esse autor assevera que a expressão exclusão se refere a:

\footnotetext{
${ }^{8}$ HOUAISS, Antônio; VILLAR, Mauro de Salles. Dicionário Houaiss da Língua Portuguesa. Rio de Janeiro: Objetiva, 2001. p.1282; BURTIN-VINHOLES, S. Dicionário francês-português, português-francês. 40. ed. São Paulo: Globo, 2003. p. 203 e 651.

${ }^{9}$ TEZANOS, J. F. La Exclusión. Madrid: [s.n.], 1999. p.10.
} 
Al proceso social que está conduciendo al establecimiento de un cierto modelo de doble condición ciudadana en las sociedades de nuestros dias, mientras que los excluídos, o al menos algunos grupos de cierta homogeneidad y localización concretas, están configurando lo que algunos denominan infraclases.

Em suma, Tezanos enfatiza a exclusão como sendo uma forma de segregação social, com as classes consideradas inferiores formadas por grupos sociais constituídos pelas vítimas principais dos denominados processos de exclusão.

Para Xiberras ${ }^{10}$, exclusão social é o produto de uma série de rupturas de vínculos sociais, que é classificada do seguinte modo: societais, produzidas pelos valores e representações sociais típicos de uma determinada sociedade; comunitárias, reveladas por meio de laços sociais primários, incluindo as relações afetivas e de parentescos; e individuais, exteriorizadas por intermédio da capacidade de comunicação com o meio exterior. De maneira que esta autora compreende o processo de exclusão como se fosse uma trajetória de sucessivas rupturas sem volta. Em conformidade com essa construção teórica, o termo exclusão social se refere ao ato de provocar o afastamento de certos grupos de indivíduos do convívio social central, colocando-os à margem da sociedade.

Do ponto de vista sociológico, a exclusão diz respeito a uma condição social de não reconhecimento do outro, até mesmo pela rejeição, tratando-se, então, a exclusão social, de uma situação em que determinadas pessoas têm dificuldades de reconhecer ao "outro" direitos que lhes são legítimos.

Por sua vez, nas dimensões jurídica e sociológica, podemos destacar duas acepções relacionadas com a nossa discussão sobre a expressão "exclusão social". Na primeira, o não reconhecimento se revela em uma evidente exclusão de direitos, ou seja, são trabalhadores pobres ${ }^{11}$ (mendigos, biscateiros, catadores de lixo etc.) que não têm uma concreta integração no mercado de trabalho, não possuindo, consequentemente, condições básicas de vida. Em geral, os efeitos sobre essas pessoas são tanto de discriminação quanto de exclusão de direitos, tendo em vista que, uma vez estigmatizados, sofrem um processo de não inserção no mundo dos direitos, ou mesmo de exclusão deste, parcial ou completamente. Nesse prisma, Hannah Arendt ${ }^{12}$ salienta a preocupante

\footnotetext{
${ }^{10}$ XIBERRAS, Martine. As teorias da exclusão: para uma construção do imaginário do desvio. Trad. José Gabriel Rego. Lisboa: Piaget, 1996. p.32 et seq.

${ }^{11}$ Sobre esta categoria de grupos sociais, Paugam denomina de "desfavorecidos"; já Castel utiliza o termo "desfiliados". Cf. PAUGAM S. La disquelification sociale: essai sur la nouvelle parvrete. 2 ed. Paris: PUF, 1993. p. 56 et seq.; CASTEL, Robert. De I' indigence à I' exclusion, la deafiliation: Precarité du trovail et vulnérabilité relationnelle. In: DONZELOT, J.; ROMAN, J. Face à l'exclusion: le modele francais. Paris: Esprit 1991, p. 137-149.

${ }^{12}$ ARENDT, Hannah. Entre o passado e o futuro. Trad. Mouro W. Barbosa de Almeida. São Paulo: Perspectiva, 1972. p.25 et seq; v.1.

As origens do totalitarismo. Trad. Roberto Raposo. 2. ed. Rio de Janeiro: Documentário, 1976. p.292-302,
} 
situação dessas pessoas, afirmando que: "[...] temos diante de nós a perspectiva de uma sociedade de trabalhadores sem trabalho, isto é, privados da única atividade que Ihes resta. É impossível imaginar algo pior [...]".

Na segunda noção de exclusão social, que na época atual se vem chamando de "nova exclusão", a ideia de não reconhecimento de direitos vai bem mais além da negação ou privação destes, visto que, utilizando a clássica frase, também proposta por Arendt $^{13}$, é inerente a um processo de "recusa ao espaço de obtenção de direitos". Em outros termos, esses grupos sociais (moradores de rua, modernômades ${ }^{14}$ etc.) vivenciam a situação de "não ter direitos a ter direitos", sem o devido reconhecimento da condição de serem seres humanos semelhantes.

No processo de construção da sociedade moderna, verificou-se a ideia de uma abertura para a mobilidade social, sendo os indivíduos os principais atores sociais. Neste diapasão, Rogers ${ }^{15}$ registra que a análise sobre a exclusão social surgiu na Europa, a partir dos seguintes fatores: crescimento dos sem-tetos e da pobreza urbana, falta de solução para o problema do desemprego de longo prazo, ausência de acesso a trabalho e rendas por parte das minorias étnicas e imigrantes, natureza precária dos empregos disponíveis e da dificuldade que os jovens passaram a ter para o acesso ao mercado laboral. Mas, salientamos que, apesar desse autor não enfatizar, especificamente, tais aspectos estão diretamente relacionados à globalização e a revolução científico-tecnológica em curso, notadamente redutora de mão de obra.

Nessa ótica, Wolfe ${ }^{16}$ vincula a questão da exclusão social com à tendência ameaçadora vivenciada por determinados grupos sociais, que até recentemente eram incluídos ao padrão de desenvolvimento, em serem marginalizados, surgindo então a classe dos "novos excluídos". Sem dúvida, a criação desta nova categoria está relacionada com o fato de que, ao produzirem pessoas supérfluas ao sistema, as recentes alterações socioeconômicas apresentam outras direções para as discussões a respeito dos problemas sociais decorrentes. Assim, se anteriormente o que mais preocupava eram as condições de exploração vivenciadas pelos trabalhadores inseridos no mercado,

${ }^{13}$ Id. As origens do totalitarismo. Trad. Roberto Raposo. 2. ed. Rio de Janeiro: Documentário, 1976. p. 232-245, v.2;

The rights of man, What are they? Modern Review. New York, 3(1), 1949. p. 30-34.

${ }^{14}$ Encontramos esta expressão no prefácio elaborado por Cristovão Buarque, na obra de: BURSZTYN, M.; e ARAÚJO, C. H. Da utopia à exclusão: vivendo nas ruas em Brasília. Rio de Janeiro: Garamond, 1997. p. 11. Portanto, os modernômades são aquelas pessoas que migram sabendo que continuarão nômades mesmo depois de chegarem aos seus destinos; ou seja, são migrantes permanentes que viverão do que sobra na modernidade: conscientes de que serão sempre excluídos, só que excluídos sem fome, graças à comida que encontram no lixo, graças à venda de resíduos que os consumidores modernos jogam fora.

${ }^{15}$ ROGERS, Garry. What is special about social exclusion approach? In: ROGES; GORE; FIGUEIREDO, 1995, p. 74 et seq.

${ }^{16}$ WOLFE, Marshall. Globalization and social exclusion: some paradoxes? In: ROGERS; GORE; FIGUEIREDO, 1995. Passim. 
na época atual tudo isso se transformou na dificuldade em encontrar outras formas de inserção, quaisquer que sejam elas. Em resumo, tal concepção confirma o fato de que realmente houve uma alteração ideológica no âmbito da sociedade contemporânea.

De fato, se os tradicionais grupos que defendiam às questões sociais, de algum modo tornaram-se vulneráveis nas suas principais reivindicações, ou seja, se antes havia toda uma reflexão crítica sobre o trabalho fabril nos clássicos modelos fordistas, caracterizados por serem alienantes, repetitivos e sem criatividade, no presente momento tais grupos se mostram perplexos com a nova problemática de encontrar alternativas para inserir os indivíduos em alguma forma de trabalho. Com efeito, a memorial imagem do trabalhador repetindo o ato de apertar parafusos, retratada brilhantemente por Charles Chaplin em "Tempos Modernos", que traduzia uma angústia vivenciada na Modernidade, nos dias de hoje tal cenário se revela como algo desejável, sendo, para determinados grupos sociais, um verdadeiro sonho quase que inatingível, pois significaria segurança e estabilidade.

Em conformidade com Gil Villa ${ }^{17}$, no Ocidente, o conceito de exclusão social tem uma conotação no contexto político moderno da democracia e, mais concretamente, no âmbito da igualdade. De forma que tal concepção de exclusão é um instrumento conceitual que serve para refletir sobre em que grau se verifica uma condição básica. Assim sendo, uma sociedade muito excludente seria injusta e pouco democrática, haja vista que se não há igualdade de oportunidades, então, não haverá uma democracia plena e, em consequência disso, se verificará a exclusão social. Nessa perspectiva, compreende esse autor que: "excluir es lo contrário de incluir, significa dejar fuera. En una sociedad, sea local o global, se refiere a dejar a un individuo fuera de algunos aspectos del juego social, no dejándole participar el mismo".

Em uma explanação mais detalhada, Villa apresenta duas abordagens para o tema da exclusão: na primeira, ela é vista por um ângulo dicotômico, ou seja, a sociedade dividida entre excluídos e integrados, sendo possível resolver tal situação por meio da vontade política dos governantes e por intermédio da solidariedade por parte da sociedade civil; já na segunda linha de pensamento, a exclusão possui em si mesma duas faces com características de exclusão e de inclusão, sendo necessário levar em consideração determinados aspectos no seu estudo, tais como os seus processos desencadeadores, os graus, a reação entre os variados tipos de exclusão, a relação entre os efeitos excludentes e includentes dos fenômenos sociais, entre outros. Ressalte-se, que esta segunda noção é bastante complexa, por ser possuidora de dimensões, de certo modo, contraditórias.

De acordo com o primeiro enfoque, a exclusão é vista principalmente como sinônimo de pobreza, sendo este significado restrito à utilização genérica da palavra. Mas, saliente-se que o termo

${ }^{17}$ VILLA, Fernando Gil. La exclusión social. Barcelona: Ariel, 2002. p. 16. 
exclusão, desde a década 70 do século passado, vem sendo igualmente utilizado se referindo não apenas a determinadas diferenças étnicas, comportamentais e físicas, bem como para descrever, em geral, os pobres, os desempregados, os sem-tetos, vagabundos, catadores de lixo e todo tipo de pessoas que vivem em condições de miserabilidade, encontrando-se nas margens da sociedade. ${ }^{18}$

Nesse sentido, Castel ${ }^{19}$ esclarece que "a exclusão vem se impondo pouco a pouco como um mot-valise para definir todas as modalidades de miséria do mundo: o desempregado de longa duração, o jovem da periferia, o sem domicílio certo, são excluídos [...]". Continuando, este autor salienta que a problemática da exclusão torna-se uma "questão social" por excelência, apresentando algumas características da exclusão que deveriam permitir o uso adequado da palavra:

A primeira razão para se desconfiar da exclusão é justamente a heterogeneidade de seus usos. Ela designa um número imenso de situações diferentes, encobrindo as especificidades de cada uma; ou seja, a exclusão não é uma noção analítica. Ela não permite conduzir investigações precisas sobre os conteúdos que pretende abranger [...]. De fato, a uma segunda razão, a principal, para se desconfiar dessa noção, pois falar da exclusão conduz a autonomizar situações-limite que só têm sentido quando colocadas em um processo. A exclusão se dá, efetivamente, pelo estado de todos os que se encontram fora dos circuitos vivos das trocas sociais.

Outrossim, no âmbito da questão social, há elementos que diferenciam as exclusões clássicas das contemporâneas, pois as primeiras eram consideradas políticas, como o produto do processo de acumulação necessária a capitalismo, caracterizada pelos conflitos entre o capital e o trabalho. Tal abordagem foi cuidadosamente explicada por Marx e Engels ${ }^{20}$, que observaram a tendência dualista das classes, descrevendo-as como a burguesa e a trabalhadora, sendo que esta categoria era formada por pessoas que defendiam uma proposta de referência alternativa, pois eram detentoras de capacidade de auto-organização e agregação social, manifestando fundamentalmente a proposta de uma nova sociedade. Com a modernização, os países foram levados a reduzir os gastos e a preservar apenas as pessoas capacitadas para servir às transformações tecnológicas, afastando assim os outros, que realizam atividades sem qualificação.

\footnotetext{
${ }^{18}$ Encontramos em Villa três graus de exclusão: primeiro (pobreza extrema, sem-teto e infância desprotegida), segunda (desempregados, emigrantes, adultos habitantes de comunidades rurais, portadores de Sida, incapacitados, hermafroditismo e minorias étinicas), terceira (homossexualismo, prostituição, toxicomania, alcoolismo e presidiários). VILLA, 2002, p. 30.

${ }^{19}$ CASTEL, Robert; WANDERLEY, Luis Eduardo W.; BELFIORE-WANDERLEY, Mariangela. Trad. Cleisa Moreno Maffei Rosa; Mariangela Belfiore-Wanderley. Desigualdade e a questão social. 3.ed. São Paulo: EDUC, 2010, p. 21-22 e 25.

${ }^{20}$ MARX, Karl; ENGELS, Friedrich. O manifesto do partido comunista. 10.ed. Trad. Marco Aurélio Nogueira; Leandro Konder. Petrópolis: Vozes, 2000, p. 66-78.
} 
Na América Latina, diferentemente da realidade europeia, a questão social exteriorizou-se, no espaço e no tempo, a partir das perspectivas da nacionalidade, da esfera estatal, da cidadania e da implantação do capitalismo. Logo, ela deve ser compreendida de forma diversa, tendo em vista as suas próprias peculiaridades (problematização nas temáticas indígena, rural, da raça negra e da mulher), mesmo que ela tenha ganho foros de emergência pública e também sido igualmente reconhecida em um momento preciso da história européia, em que se consagrou a expressão. Sem dúvida, houve uma convergência com a concepção clássica elaborada na Europa, visto que na América Latina a questão social assumiu características semelhantes às do continente europeu, com a efetivação da industrialização e da implantação do capitalismo tardio em nosso continente. Na época atual, de mundialização do capitalismo, nos setores mais modernizados, tal questão irá identificar-se, em diversos aspectos, com o formato de sua constituição nos países desenvolvidos. ${ }^{21}$

Desse modo, a exclusão social deve ser compreendida como um dos desdobramentos da questão social que surgiu a partir das grandes transformações econômicas e políticas ocorridas na Europa do século XIX, sendo tudo isso consequência do processo de industrialização decorrente do capitalismo. Mas, a partir desse cenário, a questão da exclusão social atual é bem mais problemática, possuindo, além dos elementos econômico e político, o social e o simbólico. Nesse contexto, hodiernamente a exclusão tem uma dimensão de descolamento, pois enquanto a parte integrada continua desempenhando suas atividades regularmente, a desintegrada (os excluídos) é alijada e rechaçada. Então, a exclusão social pode ser analisada por meio de um fenômeno que vem acontecendo no decorrer do tempo, com os processos sociais de evolução, dualização e segregação; ou pode ser também considerado como um mecanismo complexo e contraditório que contém, em si mesmo, a inclusão e a exclusão. Contudo, entendemos que na discussão desta temática, não se deve reduzir tal realidade de modo simplista, como bem lembra Villa ${ }^{22}$, quando afirma que:

No podemos, por ejemplo, limitarnos a pensar en términos de justos y injustos, ricos y pobres. Las lecturas demasiado sencillas de la exclusión tienen como consecuencia más directa la de extremar las categorias, aumentando el espacio que media entre excluídos e incluídos.

Como podemos observar, para esse autor, as causas da exclusão são sociais, econômicas, culturais, trabalhistas e pessoais. De modo que é a partir desta perspectiva que seguiremos para uma abordagem sobre a exclusão no contexto do direito à moradia digna, que inclusive foi contemplado no art. 6o da nossa Carta Magna de 1988; sendo que, preliminarmente, desenvolveremos uma

\footnotetext{
${ }^{21}$ WANDERLEY, Luiz Eduardo W. A questão social no contexto da globalização: o caso latino-americano e o caribenho. In: CASTEL, Robert; BELFIORE-WANDERLEY, Mariangela; Desigualdade e a questão social. 3. ed. São Paulo: EDUC, 2010. p. 65-66.

${ }^{22}$ VILLA, 2002, p.13.
} 
abordagem envolvendo a exclusão social e as concepções de direitos e cidadania social. Assim, para uma melhor exposição sobre as relações entre esses elementos, torna-se necessário partir de um marco referencial objetivando esclarecer o que é considerado como um padrão mínimo de integração e pertencimento à uma sociedade, haja vista que é nesse cenário que surge a idéia dos direitos sociais e o conceito de cidadania social.

$\mathrm{Na}$ teoria tipológica de Marshall ${ }^{23}$, a cidadania está dividida em três dimensões, correspondendo cada uma destas a um tipo de direito: o civil, o político e o social. De forma que, enquanto o componente civil é formado pelos direitos necessários à liberdade individual; o político trata do direito de participação ao exercício do poder político; e o social se refere à uma série de direitos, incluindo o da seguridade, do bem-estar e o econômico, que diz respeito ao direito de dividir o conjunto de riquezas sociais e de viver dentro dos padrões inerentes à convivência social, inclusive o sistema educacional e os serviços sociais.

Nessa perspectiva, Marshall assevera que, mesmo não se dando prioridade histórica a uma dessas formas de cidadania em relação às outras, é possível afirmar que cada tipo de cidadania pertence a um determinado momento histórico de desenvolvimento do processo civilizador. O primeiro impulso evolutivo deste processo originou a noção de cidadania civil, estando relacionado com o pensamento liberal de democracia e tendo o mercado sendo o principal núcleo institucional para o proprietário (burguês), pois era o local de suas transações econômicas; nesta dimensão, a cidadania traduz status, com os direitos de propriedade sendo desfrutados de forma passiva, pois eles limitam a ação do Estado sobre a vida dos cidadãos. Já o segundo momento, que é revelado por meio da idéia de cidadania política, é baseado, de acordo com Arendt $^{24}$, na tradição grega, estando associado com o modelo republicano de democracia, na qual o indivíduo possui um fórum, que é seu principal espaço institucional, sendo as liberdades de organização e participação política no destino da comunidade deveres dos cidadãos.

Por seu turno, a concepção de cidadania social, que para Marshall25 é tão remota quanto as já destacadas (civil e política), apenas no final do século XIX foi compreendida como categoria diferenciada. Em suma, tais elementos de cidadania formavam um conjunto indiferenciado, pois as próprias instituições eram de delimitações difusas; por conseguinte, a distinção entre elas ocorreu na própria divisão social que caracteriza o processo de modernização ocidental. Nessa conjuntura, a noção de cidadania social está associada ao surgimento de um campo social diferenciado, chamado

\footnotetext{
23 MARSHALL, T. H. Citizenship and social class. New York: Anchor Books, 1965. p.28.

${ }^{24}$ ARENDT, Hannah. A condição humana. 11.ed. Trad. Roberto Raposo. Rio de Janeiro: Forense Universitária, 2010. p. 4, 28-29 e 47 et seq.

${ }^{25}$ MARSHALL, 1965, p. 79.
} 
por Arendt de "ascenção social". Em outras palavras, com as mudanças ocorridas na sociedade, tais como as modificações das tarefas de lugar e dos recursos organizacionais, para a esfera pública, houve uma diluição da divisão entre público e político, alterando o sentido e a importância destes para o cidadão.

Em resumo, após essas considerações, percebemos que o processo evolutivo que originou a ideia de cidadania absorveu esses três tipos de direitos, estando eles diretamente articulados com os direitos do cidadão-trabalhador, que em conformidade com a legislação devem ser iguais para todos. Mas, lembramos que no atual contexto material da realidade cotidiana, tal propósito não é alcançado, principalmente pelos grupos sociais pobres e desempregados que vivem em uma sociedade desigual.

Indiscutivelmente, o fenômeno da desigualdade existe desde o início dos tempos e está presente em todas as sociedades, embora se exteriorize sob formas e configurações diferentes, sendo que podemos distinguir a desigualdade com relação ao ser, ao fazer e ao ter. Nessa construção teórica são apresentados três pressupostos: o inicial, que tem por base a idéia de que as pessoas possuem direitos básicos e iguais, não levando em consideração a forma como isso ocorre e, implicitamente, repudiando a concepção de justiça como equidade e viabilidade de convivência; em seguida, encontra-se a noção de que as vantagens e desvantagens das pessoas não são interdependentes ou discretas entre si, se não estão mutuamente condicionadas; por último, observase a acepção de que os tipos de desigualdades são variados, existindo tantos quantos queiramos adotar ou considerar.

Nessa discussão, há o entendimento de que existem duas grandes formas de desigualdades heterogêneas entre si e homogêneas interiormente -, sendo tal assertiva útil para que se apresente uma distinção operacional. Em outros termos, possuímos a desigualdade quanto ao acesso final dos recursos dos denominados bens escassos ou econômicos; e a desigualdade quanto ao acesso inicial das oportunidades de perseguir esses recursos, como, por exemplo, obter emprego, moradia digna, possibilidade de ser proprietário. Em síntese, a primeira diz respeito à desigualdade de riqueza (em sentido amplo), enquanto a segunda refere-se à desigualdade de direitos, ou seja, à desigualdade na possibilidade de realizar direitos.

Na época atual, há uma tendência no sentido de não haver necessidade de justificar a preocupação social pela desigualdade de oportunidades iniciais, pois, de certo modo, existe um consenso nas sociedades de que os seres humanos são criados iguais e assim devem ser tratados; sendo que essa questão é diferente quando se trata da desigualdade de riqueza, ou seja, do acesso de grande parte da população mundial aos bens com valor econômico. De fato, na realidade concreta, é bem visível a persistência das desigualdades, tanto no que se refere aos recursos quanto às 
oportunidades. Para melhor esclarecer essa discussão, torna-se pertinente a utilização de alguns conceitos do campo das ciências sociais relacionados com a desigualdade, ou seja, os de exploração, desigualdade de oportunidades e discriminação.

Segundo Marx ${ }^{26}$, "a história é a história do desenvolvimento das forças produtivas e toda história existente da sociedade é a história da sua luta de classes"; neste ponto de vista, a desigualdade se encontra enraizada nas razões da propriedade. Dessa forma, Marx faz uma vinculação entre o materialismo histórico, os interesses antagônicos da sociedade e a exploração da classe trabalhadora. Para este autor, os resultados do trabalho humano equivalem aos recursos, à apropriação do trabalho e à sua exploração pela classe dominante, situação esta que só será solucionada por meio da práxis. Já no entendimento de $W \operatorname{ebe}^{27}$, a questão da desigualdade está relacionada à distribuição de oportunidades vitais e ao conceito de discriminação, sendo o fazer e o ser iguais; então, para este autor, as discriminações sexual e étnica são formas de segregação social.

Como vemos, existem abordagens distintas sobre o fenômeno da desigualdade, sendo uma delas vinculada ao aspecto da exploração, que não deve ser vista como um elemento isolado, segundo o marxismo; mas, sim, como um fato multidimensional, haja vista que tem haver tanto com as relações distributivas e funcionais, que ocorrem no âmbito das esferas de produção do mercado, quanto com a própria delimitação de limites entre incluídos e excluídos, envolvendo também a participação dos mesmos nas relações sociais. Já a teoria proposta por Weber considera a desigualdade como discriminação, ao invés de exploração; então, de acordo com a corrente weberiana, tal possibilidade é bem mais intensa, pois é exteriorizada tanto pelas desigualdades de oportunidades de vida como pela forma como ela afeta a dignidade pessoal, expressando-se por intermédio de traços inatos à pessoa, como o sexo, a idade e/ou por meio dos aspectos culturais e étnicos.

Enfim, o estudo sobre as causas da exclusão social envolve inúmeros fatores relacionados com as clássicas iniquidades sociais. Todavia, pela pertinência temática deste texto, relacionado com a questão urbana, destacaremos o fenômeno da pobreza, como sendo a forma mais grave de exclusão.

A pobreza possui várias dimensões e para melhor compreendê-la é necessário observá-la por meio de indicadores ${ }^{28}$, tais como os níveis de renda, o consumo, o crescimento, os aspectos sociais, a

\footnotetext{
${ }^{26}$ MARX; ENGELS, 2000, p.66.

${ }^{27}$ WEBER, Max. Ensaios de sociologia. Trad. Waltensir Dutra. Rio de Janeiro: Zahar, 1963. p. 221-223 e 267-277.

${ }^{28}$ Veja-se como exemplo dessa abordagem, a vertente capacitária como fundamento de uma teoria de justiça proposta por Amartya Sen, que desenvolveu uma análise sobre "desenvolvimento como liberdade". Neste estudo, Sen considera aspectos como liberdades instrumentais, bases informacionais, utilidade, diversidades, capacidades, funcionalidades etc. Esse autor toma por base o Relatório Mundial sobre Desenvolvimento Humano divulgado pelo Banco Mundial. SEN, Amartya. Desenvolvimento como liberdade. Trad. Laura Teixeira
} 
vulnerabilidade, o acesso sociopolítico, entre outros. Nesse sentido, em 2005 foi desenvolvido um estudo pelo IBCA - Sovereign Comparator ${ }^{29}$, analisando comparativamente os indicadores sociais de 56 países que integram o Mercado Financeiro Internacional, onde se observou que em nenhum país a distância entre ricos e pobres é maior do que no Brasil, tendo o ranking, inclusive, revelado quantas vezes a parcela da renda nacional dos $20 \%$ mais ricos é maior do que a dos $20 \%$ mais pobres.

No Brasil, certamente, o pobre no Brasil está mais vulnerável e exposto à exclusão do que em outros países em desenvolvimento e, devido a isso, é considerado, na concepção de alguns autores, miserável, ou seja, mais que pobre. Nesta linha de pensamento, Cristovão Buarque ${ }^{30}$ apresenta um resumo sobre a situação brasileira:

Depois de 100 anos de crescimento econômico, quase 100 milhões de pessoas vivem na pobreza; destas, quase 60 milhões sobrevivem em condições de miséria, e nada menos do que 20 milhões em total indigência.

A propósito, no concernente a realidade social brasileira, um dos autores pioneiros à escrever sobre a miséria foi Josué de Castro ${ }^{31}$, que desenvolveu um mapeamento do Brasil faminto:

E quando cresci e sai pelo mundo afora, vendo outras paisagens, me apercebi com novas surpresas que o que eu pensava ser um fenômeno local, era uma drama universal. Que a paisagem humana dos mangues se reproduzia no mundo inteiro. Que aqueles personagens da lama do Recife eram idênticos aos personagens de inúmeras outras áreas do mundo assolados pela fome. Que aquela lama humana do Recife, que eu conhecera na infância, continua sujando até hoje toda a paisagem do nosso planeta como negros borrões de miséria: as negras manchas demográficas da geografia da fome.

Em última análise, a palavra "miséria", como também certos termos para exprimir pobreza, é uma expressão de significados imprecisos, então, questionamos o que significa, na realidade, ser miserável. Cremos que as pessoas percebem a miséria por meio de suas experiências pessoais, pois a pobreza é óbvia, embora seja necessário estabelecer critérios para melhor compreendê-la.

Então, para um melhor esclarecimento sobre esse aspecto, torna-se pertinente analisar a definição sobre o significado de ser pobre ou de ser miserável. Em suma, abaixo da linha da pobreza encontram-se os que não possuem renda suficiente para custear os mínimos sociais para a

Motta. São Paulo: Cia. das Letras, 2000; v. tb. BRASIL. Presidência da República. Ministério das Relações Exteriores. Relatório Nacional Brasileiro: Cúpula Mundial para o Desenvolvimento Social. Copenhague/Brasília, fev. 1995; LEN, Doyal; GOUGH, lan. A theory of human need. London: Palgrave, 1991.

29 IBCA - Sovereign Comparator Ratings-Rapid Response. Disponível em: http://rru.worldbank.org/Documens/Toolkits/Highways/pdf/.../E24.pdf. Acesso em: 29 mar. 2012.

30 BUARQUE, Cristovão. O colapso da modernidade brasileira: e uma proposta alternativa. 5.ed. Rio de Janeiro: Paz e Terra, 1991. p.15.

${ }^{31}$ CASTRO, Josué. A geografia da fome. São Paulo: Paz e Terra, 1976. p.6; 131.

Geografia da fome: o dilema brasileira - pão ou aço. 10.ed. Rio de Janeiro: Civilização Brasileira, 2010. p. 
manutenção de uma vida humana (alimentação, habitação, transporte e vestuário), considerando isso em um contexto onde a educação e a saúde são fornecidas pelo Estado; a outra é a linha da miséria ou da indigência, que determina quem não obtém o suficiente para garantir uma necessidade básica a alimentação -, e que vive de maneira primitiva. Ressalte-se que esta segunda categoria de pessoas não possuem rendas fixas mínimas e não conseguem alimentos todos os dias, nem mesmo em uma proporção necessária a manutenção vital fisiológica, que possibilite uma vida saudável e produtiva.

Após essas considerações, constatamos a presença de variados graus de exclusão, sendo a gravidade desta que define toda sua complexidade, como é o caso da pobreza severa, que se supõe como sendo a própria ameaça direta à sobrevivência, visto que ela é considerada como o vetor que mais afeta as pessoas no mundo. Portanto, é a partir dessa perspectiva que contextualizamos a questão urbana do direito à moradia digna; assim sendo, no próximo tópico, passaremos a desenvolver uma abordagem sobre o processo evolutivo da legislação urbana brasileira relacionada com o direito à moradia.

\section{A INSERÇÃO DA LEGISLAÇÃO URBANA BRASILEIRA NO ÂMBITO DA CONSTITUIÇÃO FEDERAL DE 1988}

A evolução da legislação urbanística no Brasil vem enfrentando inúmeros desafios criados pelas novas situações sociais, políticas, econômicas e ambientais decorrentes do crescimento urbano intensivo. De fato, no decorrer do tempo, os fenômenos de industrialização e urbanização vêm provocando uma grande concentração econômica, determinando, por sua vez, processos de exclusão e segregação sócio-espacial ${ }^{32}$ de grande parte da população. Nessa conjuntura, a elaboração da legislação urbana brasileira tem sido marcado a partir de interesses compatíveis com o fenômeno de acumulação de capital sem controle nas cidades, com graves consequências na vida cotidiana daquelas pessoas que têm sido tradicionalmente excluídas dessa realidade.

Então, ao invés de ser uma questão técnica, com uma resposta adequada dentro dos limites do ordenamento jurídico, a construção da legislação urbana constitui um processo político, cuja dimensão também se encontra na produção da "cidade-cidadania". ${ }^{33}$ Mas, até que isso seja equalizado, por meio da efetiva aplicabilidade material dos atuais instrumentos jurídicos que foram discutidos, legislados e promulgados, muitas pessoas ainda continuam vivendo em uma ordem

32 No trabalho da arquiteta Luciana Lago, encontramos uma importante discussão sobre a dinâmica urbana e estruturação socioespacial, no âmbito das desigualdades sociais, da crise econômica e dos novos padrões de segregação espacial na realidade urbana brasileira. LAGO, Luciana Corrêa do. Desigualdades e segregação na metrópolis: o Rio de Janeiro em tempo de crise. Rio de Janeiro: Revan, 2000.

33 FERNANDES, E. Direito do urbanismo: entre a "cidade legal" e a "cidade ilegal". In: Direito Urbanístico. Belo Horizonte: Del Rey, 1998. p. 6 e 10. 
jurídico-urbana excludente e segregadora. Indiscutivelmente, a urbanização é um fenômeno social que precisa ser constantemente analisado, para que sejam feitas as devidas adequações às realidades sociais e culturais contemporâneas, a partir de perspectivas transdisciplinares.

$\mathrm{Na}$ análise do processo de urbanização, a doutrina tem citado três paradigmas para a orientação dos estudos jurídicos no Brasil: noções diferentes da cidade, do Estado e das relações entre ambos; sendo que tais inclinações têm revelado enfoques conflitantes existentes no país, ou seja, a questão dos direitos de propriedade, do direito administrativo e a ampla abordagem no campo dos estudos sócio-jurídicos, como bem enfatiza Fernandes ${ }^{34}$ :

Já há algum tempo tem havido uma necessidade urgente de se estabelecer mais pontes entre a pesquisa urbana e os estudos jurídicos de tal forma que a natureza e a dinâmica do processo de urbanização sejam melhores conhecidos. Na minha opinião, o enfoque da Sociologia do Direito é o mais apropriado para tanto.

Em meados da última década do século passado, gradativamente foi sendo elaborada uma legislação urbanística no Brasil, tendo como fatores precursores, entre outros, Estudos Especializados, Seminários e a Lei do Parcelamento do Solo Urbano, culminando com a promulgação da Constituição Federal de 1988, que prevê a matéria da Política Urbana, estabelecendo um novo paradigma de orientação social para o Direito Urbano Brasileiro. Saliente-se que esta Carta Magna se refere literalmente ao Direito Urbanístico (art. 24, I), ao dispor quanto à competência para legislar sobre ele, tendo, inclusive, inserido o Município no âmbito da Federação Brasileira, ao lado dos Estados e Distrito Federal (arts. 24, I e $\S \S 1$ ㅇ e 2o; 30, I, II e VIII; e 182 da CF/88). Assim, visando o cumprimento do objetivo primordial do urbanismo, qual seja, o ordenamento das cidades para propiciar às pessoas suas funções sociais básicas, tais como moradia, transporte, lazer, trabalho etc., o Município deverá legislar sobre vários aspectos.

Em conformidade com as reflexões expostas, observamos que a política de desenvolvimento urbano deve ser efetivada com o propósito de possibilitar o desenvolvimento sustentável ${ }^{35}$, objetivando o atendimento das necessidades fundamentais das gerações presentes e futuras; ou seja, a proposta seria a compreensão do desenvolvimento urbano como uma política pública que tenha como finalidade a concretização dos direitos humanos, garantindo assim uma vida digna. Mas, para o desenvolvimento de tudo isso, é preciso que determinadas medidas sejam implementadas, sobretudo,

\footnotetext{
${ }^{34}$ FERNANDES, 1998, p. 222 e 228.

35 Nesse sentido, o trabalho desenvolvido por Acselrad, Mello e Bezerra, apresenta a problematização relacionada com o tema da Agenda 21 Local, onde há uma discussão sobre o fenômeno da "ambientalização" dos conflitos sociais, das políticas públicas e de sua legitimação social e política a partir do estabelecimento progressivo de uma nova linguagem. ACSELRAD, Henri; MELLO, Cecília Campelo do Amaral; BEZERRA, Gustavo das Neves. Cidade, ambiente e política: problematizando a Agenda 21 local. Rio de Janeiro: Garamond, 2006.
} 
com a participação do povo e voltadas para um meio ambiente saudável, enfrentando as causas da pobreza, apresentando novos padrões de produção e consumo sustentáveis etc.

Portanto, as funções sociais da cidade estarão sendo desenvolvidas de forma adequada e integral quando houver redução das desigualdades sociais, promoção da justiça social e melhoria da qualidade de vida, evitando também medidas e ações de agentes (públicos e privados) que resultem em situações de segregação e exclusão de grupos e comunidades carentes. Logo, enquanto estas pessoas não tiverem acesso à moradia, transporte público, saneamento básico, saúde, educação, segurança, trabalho digno, etc., não há como reconhecer que a cidade esteja atendendo à sua função social.

Com a Constituição Federal de 1988, o processo de tomada de decisões sobre questões urbanas foi reconhecido como político, devendo haver toda uma definição sobre os padrões e limites de exploração econômica da propriedade, sendo a população reconhecida como agente político. Então, foi criado um novo direito social - o direito ao planejamento urbano, devendo a legislação urbanista propor instrumentos eficazes para que as autoridades públicas controlem adequadamente o processo de uso e desenvolvimento do solo, criando direitos, obrigações e responsabilidades, tanto para os agentes privados quanto para os públicos; além do mais, esse planejamento deverá ter uma dimensão sociopolítica, na qual participem diferentes interesses e grupos sociais.

Mas, acima de tudo, a meta final será sempre a busca por uma melhor qualidade de vida, sendo que, voltamos a lembrar, isso só será possível com a devida e ampla participação popular no processo de tomada de decisões, visto que é uma poderosa forma de enfrentar os problemas urbanos, no intuito de possibilitar a promoção de mudanças imprescindíveis na atual situação de injustiça social que vivem milhões de inquilinos, favelados, moradores de lixões e periferias etc. Enfim, não se pode mais aceitar que essas pessoas continuem a serem excluídos da administração de suas cidades e dos processos políticos e jurídicos que constituem a ordem urbana.

Ademais, é importante registrar que nessas décadas de neoliberalismo, o mecanismo para sustentar soluções imediatas, independentemente de sua adequação às realidades sociais e econômicas, foi a receptividade de um discurso único, estando o modelo de primazia do capital recebendo apoio da mídia para validar tautologicamente as soluções; ou seja, por meio da reafirmação destas como forma de sua comprovação, não importando o problema, pois a melhor opção será a que interessar a lógica do capitalismo. Porém, a perspectiva da dialética progressista propõe uma outra alternativa, partindo do diagnóstico das realidades para depois se chegar às soluções, avaliando cada caso específico em conformidade com as respectivas situações concretas. 
De maneira que é por meio do conhecimento dos problemas e de suas implicações em profundidade que torna-se possível encontrar saídas para um mundo sustentável e pessoas saudáveis.

Nesse contexto, o urbanismo brasileiro não vem tendo um efetivo comprometimento com a realidade concreta, e sim com uma ordem que diz respeito apenas a uma parte da cidade. Assim, podemos dizer que se trata de ideias fora do lugar porque, pretensamente, a ordem se refere a todos os indivíduos, de acordo com os princípios do modernismo ou da racionalidade burguesa; mas, também, é possível afirmar que as ideias estão no lugar por isso mesmo, pois elas se aplicam a uma parcela da sociedade reafirmando e reproduzindo desigualdades e privilégios. Logo, para a cidade ilegal não há planos, nem ordem, muitas vezes, não sendo conhecida nem mesmo as suas dimensões e características, tratando-se então de um lugar fora das ideias. ${ }^{36}$

Indiscutivelmente, não é por falta de planos e nem de legislações que as cidades brasileiras crescem de modo predatório, haja vista que um abundante sistema regulatório normatiza a produção do espaço urbano brasileiro, com rigorosas leis de zoneamento, exigentes textos legais de parcelamento do solo, códigos de edificações, entre outros instrumentos que são formulados por corporações profissionais que desconsideram a condição de ilegalidade em que vive grande parte da população urbana brasileira em relação à moradia e à ocupação da terra, demonstrando assim que a exclusão social passa pela aplicação discriminatória da lei. Realmente, a pouca eficácia dessa legislação é apenas aparente, visto que constitui um mecanismo fundamental para o exercício arbitrário do poder. Por conseguinte, a ocupação ilegal da terra urbana é implicitamente tolerada como parte do modelo de desenvolvimento urbano no Brasil; além disso, saliente-se que, ao lado da detalhada legislação urbanística, a ilegalidade na provisão de grande parte das moradias urbanas é fundamental para a manutenção do baixo custo de reprodução da força de trabalho, como também para um mercado imobiliário especulativo, que tem sua sustentação a partir de uma estrutura fundiária arcaica.

No Brasil, a leitura das justificativas de planos ou projetos de leis urbanísticas, de certa forma, revela o cumprimento de um papel com tendência ao plano do discurso e da retórica, destacando alguns aspectos para ocultar outros. Consequentemente, há "leis que pegam" e "leis que não pegam", sendo mais frequente parte do projeto ser cumprido ou então ele ser aplicado apenas à parte da cidade, acompanhando a lógica da cidadania restrita a alguns.

Baldez ${ }^{37}$, em sua importante retrospectiva histórica sobre a legislação urbanística brasileira, chama a atenção para a contradição representada pelo aparato regulatório que é erigido após 1850, com a finalidade de proteger a propriedade privada da terra contra as ocupações, quando até esta

\footnotetext{
${ }^{36}$ MARICATO, E. As ideias fora do lugar e o lugar fora das ideias: planejamento urbano no Brasil. In: ARANTES, O; VAINER, C. A cidade do pensamento único: desmanchando consensos. 5. ed. Petrópolis: Vozes, 2009. p. 122

${ }^{37}$ BALDEZ, M. Solo urbano, reforma urbana, propostas para a Constituinte. Rio de Janeiro: Fase, 1986. p. 27
} 
data a posse era norma para consegui-la. Nessa perspectiva, o projeto liderado por José Bonifácio, de implantar uma colonização branca combinada à pequena propriedade privada, que seria financiada com a venda das terras devolutas, foi derrotado pelos latifundiários; consequentemente, a implementação da lei formalizou o latifúndio, sendo a definição quanto as terras devolutas, após 1850, uma das maiores farsas que marcaram a história do Brasil. Com efeito, o caso da demarcação destas terras, prevista na mencionada legislação, revela uma história de leis e decretos não aplicados, que são continuamente sucedidos por outras medidas igualmente simbólicas do ponto de vista jurídico.

Registre-se, também, que os conflitos sociais que marcaram todo o século XIX, revelaram a forte relação que articula o acesso a terra com a mão-de-obra e a colonização, tendo em vista que o latifúndio persiste, mais de quatro séculos, a todas as propostas de mudança. Por conseguinte, o processo de urbanização foi fortemente marcado por essa herança; mas, apesar de tal processo no Brasil ter ocorrido praticamente no século XX, sob o regime republicano, as raízes coloniais calcadas no patrimonialimo e nas relações de favor (coronelismo) ainda continuam presentes nessa conjuntura. Em suma, a terra é um aspecto de alta complexidade na sociedade brasileira, notadamente nas cidades, haja vista que a legislação vem mostrando-se ineficaz quando contraria interesses de proprietários ou mesmo quando o mérito são os direitos sociais. ${ }^{38}$

Mais especificamente com relação ao que chamamos de favela, é notória a sua complexa condição jurídica de propriedade do lote; mas, etmologicamente, outras denominações igualmente são utilizadas nas diversas regiões do Brasil: "área de posse", em Goiânia; "vilas", em Porto Alegre; "comunidades", no Rio de Janeiro etc. Em resumo, a caracterização jurídica de propriedade é que vale na definição, já que somente ela assegura o direito de permanência no local, pois trata-se da ocupação da terra alheia pública ou de propriedade confusa, por falta de alternativas, na maioria dos casos. Realmente, os dados mostram que a ocupação informal de terras é quase mais regra do que exceção nas grandes cidades, não havendo, portanto, números precisos sobre a ocorrência de favelas ou de loteamentos ilegais em todo o Brasil. Assim, seja por falhas metodológicas ou mesmo por dificuldades óbvias de conhecer a titularidade da terra sobre a qual as favelas se instalam, o Instituto Brasileiro de Geografia e Estatística (IBGE) apresenta dados bastantes subdimensionados.

Feitas essas explanações, compreendemos que toda essa situação é resultado de um processo de urbanização que segrega e exclui. Como já destacamos, no Brasil tal prática se deu praticamente no século XX, sendo que ainda conserva muitas das raízes da sociedade patrimonialista e clientelista, próprias do período pré-republicano. Registre-se que, no decorrer da urbanização, é também evidenciado o aspecto da industrialização com baixos salários, com a consequente restrição para o

${ }^{38}$ MARICATO, 2009, p. $150-151$. 
mercado residencial, ou seja, o valor de reprodução da força de trabalho não inclui o custo da mercadoria habitação, fixado pelo mercado privado; logo, o operário da indústria brasileira, e mesmo muitos daqueles regularmente empregados pelo modelo fordista (indústria automobilística), não ganham o suficiente para pagar o preço da moradia fixado pelo chamado mercado formal. Sem embargo, no Brasil, onde jamais o salário foi regulado pelo preço da moradia, a favela ou o lote ilegal combinado à autoconstrução foram partes integrantes do crescimento urbano sob a égide da industrialização; por conseguinte, o consumo da mercadoria habitação se deu, em grande parte, fora do mercado caracterizado pelas relações capitalistas de produção. ${ }^{39}$

Outra relevante característica advinda com a urbanização é o fato das gestões urbanas municipais possuírem uma cultura de investimento regressivo, com as obras de infraestrutura priorizando a especulação fundiária e não a democratização do acesso à terra para moradia. Nessa conjuntura, os proprietários de terras e capitalistas das atividades de promoção imobiliária e construção são grupos tradicionalmente detentores de poder no âmbito do processo de definição das realizações orçamentárias municipais. Silva ${ }^{40}$, ao analisar essa matéria, assevera que:

As diversas instâncias de governo, em países latino-americanos, intencionalmente ou porque são levadas a isso, acabam por beneficiar o capital imobiliário ou os grandes grupos privados quando da alocação dos investimentos públicos. E importante notar, porem, que essa atuação não é desprovida de uma justificativa, ao contrário, ela costuma apoiar-se na proposição, muito difundida (e cara aos neoclássicos), de que o critério prioritário seria o da eficiência econômica desse procedimento.

Com efeito, ao invés de concretizar o caráter público e social dos investimentos municipais em uma cidade com inúmeras carências, o governo municipal atua de acordo com interesses privados, em especial de empreiteiras e agentes do mercado imobiliário. Por exemplo, nas próximas décadas, o espaço privilegiado deste mercado ${ }^{41}$, para as próximas décadas, na cidade de São Paulo, por exemplo, é o entorno do Rio Pinheiros, onde se concentram altos investimentos públicos e privados, bem como se encontram as sedes das grandes multinacionais ou empresas nacionais. Nesse prisma, vários urbanistas justificam esses investimentos por meio da chamada "teoria do bolo"; ou seja, essa localização teria maior potencial de atrair, por efeito sinérgico, outras aplicações financeiras e novos

\footnotetext{
${ }^{39}$ MARICATO, 2009, p. 155 - 156.

40 SILVA, F. Recuperação de mais-valias fundiárias urbanas na América Latina: debilidade na implementação, ambiguidades na interpretação. (Tese de Doutorado) São Paulo: FAUUSP, 1999. p. 47.

${ }^{41}$ Nesse sentido, cumpre destacar o importante trabalho no plano da arquitetura da Profạ. Bogéa, onde são discutidos os aspectos arquitetônicos com as tendências modernas da época atual. BOGÉA, M. Cidade errante: arquitetura em movimento. São Paulo: SENAC, 2009.
} 
empregos, ao invés de que se esses empreendimentos fossem feitos na periferia, não teriam o mesmo efeito reprodutor. ${ }^{42}$

Para dar uma ideia da dimensão, apenas no município de São Paulo, há aproximadamente dois milhões de pessoas que moram em favelas. Mas, não é em qualquer localização que a ocupação informal de terras urbanas é tolerada, tendo em vista que nas áreas valorizadas pelo mercado a lei se aplica. Tomemos como exemplo, a Zona Sul carioca, onde existem concentrações de moradias de alta renda ${ }^{43}$, sendo que tais localidades apresentam menor ocorrência de núcleos de favelas, como mostram os levantamentos cartográficos da prefeitura do Rio de Janeiro e do Laboratório de Habitação e Assentamentos Humanos (LABHAB) para São Paulo. Todavia, isso não é devido a aplicação da norma jurídica, mas em virtude da imposição da lei de mercado, demonstrando que nas áreas desvalorizadas ou inviáveis para a especulação imobiliária (beira de córregos, áreas de proteção ambiental etc.), a lei pode ser transgredida. Então, o direito à ocupação informal de terras é até admitida, mas não o direito à cidade, sendo o critério definidor o fator mercadológico ou espacial. Ademais, acrescente-se a tudo isso o fato de que a exclusão territorial tem como consequências a predação ambiental, o aumento da criminalidade e a violência urbana.

Outrossim, observa-se uma certa correspondência entre a rede hídrica e a localização das favelas no ambiente urbano ${ }^{44}$, ou seja, o confinamento dos córregos, devido à ocupação de suas margens, promove problemas como, por exemplo, obstruções constantes com lixo, dificuldade de acesso à máquinas e caminhões para limpeza, enchentes decorrentes dos entupimentos e, finalmente, a disseminação de doenças, devido às águas que transportam para o interior das favelas material contaminado. Assim, as áreas ambientalmente frágeis - beira de córregos, rios e reservatórios, encostas íngremes, mangues, terrenos alagáveis, fundos de vale etc. - por serem possuidoras destas condições, merecem legislação especifica, visto que não interessam ao mercado legal, pois são os espaços que "sobram" para a moradia de grande parte da população.

42 SMOLKA, M. Velhas novidades na agenda do Banco mundial para a política urbana nos anos 1990. In: GONÇALVES, M. F. (Org). O novo Brasil urbano. Porto Alegre: Mercado Aberto, 1995;

SMOLKA, M.; FURTADO, F. Argumentos para a reabilitação do IPTU e do ITBI como instrumento de intervenção urbana (progressista), Revista Espaço e Debates, ano XVI, n.39, 1996.

43 Encontramos, no trabalho de Moreira, uma exposição circunstanciada de motivos justificadores para as concentrações de moradia de alta renda, envolvendo determinantes econômicos, culturais, sociais e políticos. Cf. MOREIRA, C. C. A cidade contemporânea: entre a tabula rasa e a preservação - cenários para o Porto do Rio de Janeiro. São Paulo: UNESP, 2004.

${ }^{44}$ Observamos uma importante abordagem sobre a questão das favelas no ambiente urbano no trabalho do Silva, onde este autor discute os conceitos de favelas pelo IBGE, levando em consideração a pobreza a degradação ambiental presentes nas ideias de cidade formal e cidade informal. Cf. SILVA, J. C. A. Favelas e meio ambiente urbano. In: DALLARI. A. A.; DI SARNO, D. C. L. (coords). Direito urbanístico e ambiental. 2. ed. Belo Horizonte: Fórum, 2011. 
Enfim, diante da dimensão que está assumindo a "não cidade", ou a cidade dos excluídos ou favelados, questionamos como algo tão notório ainda permanece quase invisível? De certa forma, acreditamos que a tensão existente entre a cidade formal e a cidade ilegal ${ }^{45}$ é dissimulada, pois, além da utilização dos investimentos públicos no sistema viário, a legislação urbanística se aplica praticamente à cidade "oficial", onde os serviços de manutenção das áreas públicas, da pavimentação, da iluminação e do paisagismo são eficazes. Ressalte-se que, muito embora os equipamentos sociais se concentrem nos bairros de baixa renda, sua manutenção é sofrível. De modo que a gestão urbana e os investimentos públicos aprofundam a concentração de renda e a consequente desigualdade social; mas, a representação da "cidade" é uma construção ideológica que torna a condição de cidadania um privilégio e não um direito universal, com uma parte da cidade tomando o lugar do todo. ${ }^{46} \mathrm{Em}$ outros termos, a cidade da elite representa e encobre a cidade real, sendo que tal representação não tem a função apenas de encobrir privilégios, possuindo também um papel econômico ligado à geração e captação da renda imobiliária.

Portanto, no tópico seguinte passaremos a desenvolver uma abordagem considerando o caso específico do paradoxo das favelas presentes na cidade do Rio de Janeiro, como uma expressão da proporção das desigualdades sociais ainda existentes no Brasil em pleno século XXI.

\section{O PARADOXO DAS FAVELAS DO RIO DE JANEIRO COMO REFLEXO DAS DESIGUALDADES SOCIAIS: O BRASIL DO SÉCULO XXI}

No contexto histórico brasileiro, foi possível evidenciar que o planejamento urbano brasileiro revela a existência de uma verdadeira barreira entre sua retórica e prática, que emerge desde sua base marcada por contradições, ou seja, direitos universais, normatividade cidadã - no texto e no discurso - versus favor, discriminação e desigualdade - na prática da gestão urbana. Certamente, é por esse motivo que grande parte das pesquisas relacionadas com o urbanismo se restringe à análise das ideias, como se o objeto estivesse restrito a estas, não incluindo a evolução do espaço e das práticas sociais. Desse modo, acreditamos que, desde o período colonial, esse é o fundamento estrutural das teses que afirmam a relevância da atividade de planejamento urbano na história das nossas cidades. ${ }^{47}$

Nesse sentido, esclarece Maricato ${ }^{48}$ que no Brasil-Colônia, a concessão da autonomia municipal tinha seu acompanhamento pela terra para uso coletivo e expansão da vila ou cidade que

\footnotetext{
45 FERNANDES, 1998, p. 6.

46 MARICATO, 2009, p. 165.

47 MARICATO, 2009, p.121 et seq.

${ }^{48}$ Id. Habitações e cidade. São Paulo: Atual, 1997. p.21.
} 
era sede do município. Assim, o rossio era a denominação dada a esse patrimônio municipal, sendo composto por uma porção de terra contígua à vila ou cidade, destinando-se a fornecer lenha para o fogo, madeiras para as construções e pastagem para os animais que pertencessem aos moradores locais. Já a Câmara Municipal e os administradores locais eram quem tinham a competência de doar terras - as datas - a quem solicitasse, a fim de morar ou produzir, sendo elas gratuitas, mas com a condição de ocupação, produção e pagamento de dízimo. Em suma, tal prática se prestou ao exercício arbitrário do poder dos burocratas e grandes proprietários, exteriorizando, novamente, uma certa falta de fronteiras entre o público e o privado, relação esta que é característica de, pratricamente, toda nossa história.

Do período de 1822 a 1850, com a indefinição do Estado em relação à ocupação da terra, esta é doada de forma indiscriminada, sendo nesta época que se consolida o latifúndio brasileiro, caracterizado pela expulsão de pequenos posseiros, que habitualmente ocupavam as terras virgens, com sua posterior substituição pelos tradicionais proprietários rurais. Então, devido as dificuldades na tramitação do projeto de lei que iria definir regras para a comercialização e propriedade da terra, a proposta liberal ${ }^{49}$ que pretendia utilizar as terras devolutas (pertencentes ao Estado) para com sua venda financiar uma colonização branca (imigração de europeus), baseada na pequena propriedade, não obteve sucesso, restando apenas uma detalhada exposição de motivos fundamentada nas virtudes do progresso das relações capitalistas. ${ }^{50}$

Como pudemos observar, a reconstituição histórica das variadas formas de habitar tem sido objeto de estudo entre pesquisadores brasileiros. No caso específico do aparecimento e difusão das favelas pelo espaço da cidade, como uma forma de morar presente em todo o país, tal denominação passou, inclusive, a integrar o vocabulário acadêmico internacional. No contexto histórico brasileiro, é possível resgatar o conceito de favela nas palavras de Marins ${ }^{51}$, quando afirma: "[...] Na vizinhança do Cabeça de Porco surgia a 'Favela', apelido que seria dado ao morro da Providência pelas tropas vindas de Canudos em 1897, as quais estacionaram ali e acabaram denominando o local desse nome por associação a plantas com favas, comuns tanto no morro carioca quanto nas cercanias do arraial de Antônio Conselheiro, o Belo Monte". Nessa mesma perspectiva, Medina ${ }^{52}$ esclarece que a expressão

49 Encontramos esta perspectiva no trabalho de Vicente Barretto, onde este autor desenvolve uma abordagem do modelo liberal protagonizado no pensamento de José Bonifácio, a partir das características do modelo político liberal brasileiro. Cf. BARRETTO, Vicente. Ideologia e política no pensamento de José Bonifácio de Andrade e Silva. Rio de Janeiro: Zahar, 1977.

50 MARICATO, 2009, p. 22-23; OSÓRIO, Letícia Marques. Direito à moradia adequada na América Latina. In: ALFONSIN, Betânia; FERNANDES, Edésio. (Orgs.) Direito à moradia e segurança da posse no Estatuto da Cidade: diretrizes, instrumentos e processos de gestão. Belo Horizonte: Forum, 2004. p. 21 et seq.

51 MARINS, Paulo César G. História da vida privada no Brasil. 3.ed. São Paulo: Cia das Letras, 1998. p. 136.

52 MEDINA, Carlos Alberto. A favela e o demagogo. São Paulo: Martins Fontes, 1964. 
favela provém de uma planta picante que predominava nos morros que circundavam Canudos, no Nordeste, tendo esse sido o nome que os soldados sobreviventes da guerra de Canudos deram ao morro da Providência, no Rio de Janeiro, onde se instalaram quando vieram à capital da república solicitar apoio e assistência do governo em 1900. De modo que o termo favela rapidamente se generalizou, passando a designar todas as formas de aglomerações de moradias com características semelhantes.

Quanto ao conceito jurídico das favelas ${ }^{53}$, em conformidade com Edésio Fernandes ${ }^{54}$, são assentamentos humanos precários que resultam originariamente da ocupação informal de áreas urbanas privadas e públicas; porém, o que as distingue juridicamente das outras formas de ocupações precárias da terra urbana, comuns no Brasil, como, por exemplo, os chamados loteamentos "clandestinos" ou "irregulares", é basicamente o fato de que os favelados - pelo menos no momento da ocupação original da terra - não têm qualquer título de posse ou propriedade.

Por sua vez, desde 1950, para o Instituto Brasileiro de Geografia e Estatística (IBGE) ${ }^{55}$, que foi igualmente enfatizado nos Censos de 1980 e 1991, bem como na Contagem de População de 1996, a conceituação oficial considerou como favelas os aglomerados que possuíssem, total ou parcialmente, as seguintes características: proporções mínimas - agrupamentos prediais ou residenciais formados com um número geralmente superior a cinquenta; tipo de habitação - predominância de casebres ou barracões de aspecto rústico, construídos principalmente com folhas de flandes, chapas zincadas ou materiais similares; condição jurídica da ocupação - construções sem licenciamento e sem fiscalização, em terrenos de terceiros ou de propriedade desconhecida; melhoramentos públicos ausência, no todo ou em parte, de rede sanitária, luz, telefone e água encanada; e urbanização - área não urbanizada, com falta de arruamento, numeração ou emplacamento. De maneira que o IBGE, desde então, continua basicamente utilizando a mesma definição para o que denomina aglomerado subnormal, ou seja, a favela.

Abreu $^{56}$, em uma importante abordagem a partir das áreas da arquitetura e do urbanismo, que tem por objetivo analisar a influência das políticas públicas sobre a distribuição espacial da população de baixa renda na área Metropolitana do Rio de Janeiro. Em síntese, esse autor realizou

\footnotetext{
${ }^{53}$ Sobre o conceito jurídico de favela, Gonçalves apresenta um importante trabalho a partir das perspectivas de construção, (des) construção e reconstrução de tal conceito; para tanto, este autor utiliza as categorias de exclusão, erradicação, remoção e integração das favelas à cidade. Cf. GONÇALVES, Rafael Soares. Favelas do Rio de Janeiro: história e direito. Rio de Janeiro: Pallas/PUC-Rio, 2013.

54 FERNANDES, Edésio. A regularização de favelas no Brasil: o caso de Belo Horizonte. In: (Org.). Direito Urbanístico. Belo Horizonte: Del Rey, 1998. p. 133.

${ }^{55}$ Cf. GUIMARÃES, A. P. As favelas do Distrito Federal. Revista Brasileira de Estatística, v.14, n. 51, p. 250-255, jul. /set. 1953

${ }^{56}$ ABREU, Maurício de A. A Evolução Urbana do Rio de Janeiro. Rio de Janeiro: IPLANRIO, 1997.
} 
consultas em livros, relatórios, artigos, entre outras fontes que tratam dos mais variados aspectos da evolução urbana da cidade em análise, no intuito de explicar o presente por intermédio do processo histórico que Ihe deu forma e conteúdo; ou seja, seu escopo é revelar que "o alto grau de estratificação social do espaço metropolitano do Rio de Janeiro, na atualidade, é apenas a expressão mais acabada de um processo de segregação das classes populares que vem se desenvolvendo no Rio há bastante tempo". Neste sentido, é pertinente destacar o estudo realizado por Lago ${ }^{57}$, que apresenta uma retrospectiva histórica do processo de segregação do espaço metropolitano do Rio de Janeiro, mais especificamente refletindo sobre a estruturação socioespacial desta metrópole nos anos 70 do século passado, bem como discorrendo sobre as transformações e permanências dessa dinâmica, nos anos 80 deste mesmo período.

Em suma, a formulação da obra de $A b r e u^{58}$ tem como estímulo um conjunto de fenômenos sociais já bem evidenciados por pesquisas científicas que, por um lado, se exterioriza por meio do empobrecimento da população brasileira com aumento da desigualdade de renda, precarização do trabalho, progressiva vulnerabilidade do trabalhador, e, ainda, intensa crise habitacional. Por outro lado, é observada a emergência de uma nova configuração espacial nas principais cidades brasileiras, que tem sua caracterização pela exclusividade das áreas residenciais e comerciais, bem como pela privatização dos espaços públicos e estigmatização dos ambientes populares, sendo tais fenômenos úteis para a discussão sobre a problemática relacionada com as desigualdades socioespaciais no âmbito metropolitano carioca, tendo como referência analítica o modelo núcleo-periferia. De forma que, no decorrer do tempo, o alto grau de concentração das atividades econômicas e de infraestruturas básicas dos núcleos urbanos, como também o padrão de distribuição da população pobre pela metrópole, foram as bases para que tal modelo predominasse nos estudos sobre segregação urbana.

De um modo geral, Abreu apresenta uma reconstrução da evolução urbanística, articulando-o com o desenvolvimento da formação social, ocorrido na cidade do Rio de Janeiro desde o início do século XIX até o momento atual, sempre procurando destacar os fatores econômicos, sociais e políticos que impulsionaram o país neste mesmo período. Nessa conjuntura, o Estado, tendo como objetivo principal alcançar a eficiência econômica em todos os setores de atuação, é considerado como um dos principais responsáveis pela estruturação urbana no tempo; ressaltando-se, também, a participação do capital e o estabelecimento de políticas públicas que originou o modelo segregador do espaço carioca. Portanto, na concepção desse autor, com a qual concordamos, atualmente as áreas

\footnotetext{
57 LAGO, 2000, passim.

${ }^{58}$ ABREU, 1997, passim.
} 
metropolitanas brasileiras são conclusões espaciais delineadas a partir da formação social brasileira, exteriorizando as coerências e as contradições dos sistemas econômico, institucional e ideológico prevalecentes no país.

Sem dúvida, a situação vivenciada no Rio de Janeiro é bastante significativa, visto que, além de ter sido a capital do Brasil, de 1763 a 1960, esta cidade foi, praticamente, a mais populosa do país durante quase todo esse período. Mas, no percurso histórico deste município, no século XIX foi observada a passagem de uma cidade de traços coloniais para um espaço urbano com características capitalistas, com destaque para as alternativas de mobilidade viária por meio de veículos sobre trilhos à tração animal (bondes de burro) e, posteriormente, os trens. Já no início século XX, notadamente com as ações do prefeito Francisco Pereira Passos, ocorreram grandes transformações, principalmente pela necessidade de adequar a forma urbana às respectivas criação, concentração e acumulação do capital.

Ademais, registre-se a administração de Carlos Sampaio, com ênfase para a preocupação deste com o Primeiro Centenário da Independência do Brasil, tendo este prefeito realizado importantes obras como a retirada do Morro do Castelo, bem como do Bairro da Misericórdia, tudo isso em nome da "aeração e higiene" urbana. Com Washington Luís na presidência, foi nomeado Prefeito do Distrito Federal o Dr. Antônio Prado Júnior que, por sua vez, propôs um Plano Urbanístico de altíssimo custo, tendo sido contratado um grupo de técnicos franceses liderados por Alfred Agache, que apresentou o denominado Plano Agache, que jamais foi executado na íntegra. O período de 19301964 tem sua caracterização por ser uma época de transição na evolução da organização social brasileira, devido ao caráter contraditório da Revolução de 1930, que, por um lado, tinha o objetivo de desestabilizar o poder da aristocracia cafeeira, já por outro, não apresentava nenhuma alternativa consolidada que fosse capaz de substituí-la no poder.

Entretanto, a evolução do espaço urbano carioca no período entre 1930 e 1964 é tão contraditória quanto à própria época, haja vista que desde 1930 a cidade já se encontrava bastante estratificada; ou seja, as classes altas predominantemente habitavam na "nova" Zona Sul, classes médias na antiga Zona Sul e na Zona Norte, e classes pobres nos Subúrbios. Então, desde esse período que já era verificado um crescimento tentacular da cidade, determinado principalmente pelo aumento das distâncias entre local de trabalho e residência, exigindo deslocamentos cada vez maiores. Mas, saliente-se que tal ampliação do espaço urbano não foi acompanhado por melhoria no sistema de transporte ferroviário e, mesmo quando isto aconteceu, no final da década de 30 do século passado, os subúrbios já estavam demasiadamente ocupados, só restando a população pobre a fixação em áreas distantes, para além da fronteira do Distrito Federal. Portanto, se o espaço formal (legalizado, 
oficial etc.) oferecia apenas uma localização física, por outro lado eram observadas opções próximas, exteriorizadas por terrenos ainda não ocupados, devido ao fato de apresentarem visíveis dificuldades à especulação imobiliária. Então, a decisão de ocupar ilegalmente (invadir) esses terrenos, que já haviam sidos tomados nas décadas anteriores, restringia-se às áreas centrais e suas proximidades, pois era onde estavam localizadas quase todas as oportunidades de emprego.

Assim sendo, as favelas proliferaram no Rio de Janeiro numa época que já havia controles urbanísticos formais, sendo que elas eram pouco afetadas por eles, tendo este fato sua explicação a partir do fluxo migratório que então se verificava, que inclusive comprometia a efetivação de qualquer ação coercitiva por parte do poder público; além de que, essa mesma mão-de-obra, de custo baixo, era necessária à indústria, ao comércio e à burguesia em geral. Ademais, acrescente-se a tudo isso a natureza populista ${ }^{59}$ desse período, que especialmente a partir de 1945 vivenciou o advento de uma fase "democrática", na qual as favelas, se eram consideradas "chagas da cidade" no discurso formal, eram igualmente o reduto de inúmeros votos ${ }^{60}$ e, portanto, "intocáveis".

Nessa ótica, é pertinente destacar o pensamento de Ventura ${ }^{61}$, quando analisa a trajetória do progresso do Rio de Janeiro como sendo uma "cidade partida", ou seja:

Na verdade, durante este século, desde a reforma de Pereira Passos e passando pelos Planos Agache e Doxiadis, a opção foi sempre pela separação, senão pela simples segregação. A cidade civilizou-se, modernizou-se expulsando para os morros e periferias seus cidadãos de segunda classe. O resultado dessa política foi uma cidade partida. Juntá-la talvez seja tarefa para o próximo século, mas será preciso começar já - até porque a política de exclusão foi um desastre. Não apenas moral e humanitário, mas também do ponto de vista da eficácia. O seu principal produto, o apartheid social, corre risco de ter o destino que teve o apartheid racial em outros lugares.

No Rio de Janeiro, entre outros Estados brasileiros, geralmente as invasões se dão gradualmente, sem nenhum planejamento. Mas, as ocupações coletivas de terras existem, sendo, em sua maioria, ocasionadas pela conjuntura política-econômica vivenciada no país. Desde a década de 70 do século XX, alguns municípios vêm tentando investir nas favelas, reconhecendo sua existência

\footnotetext{
${ }^{59}$ Sobre esta perspectiva, vide o trabalho de SCHMIDT \& FARRET, quando propõem a discussão sobre a questão urbana a partir da abordagem "e o sonho acabou... na periferia", isso no âmbito da cidade do populismo e da cidade do autoritarismo. Cf. SCHIMIDT, Benício; FARRET, Ricardo. A questão urbana. Rio de Janeiro: Zahar, 1986. p. 13 et seq.

${ }^{60} \mathrm{~A}$ dimensão eleitoral relacionada às favelas é apresentada, de forma articulada, com as relações política-favela e conjunto residencial, no estudo de Valladares. Cf. VALLADARES, Lícia do Prado. Favela, política e conjunto residencial. In: BLAY, Eva Alterman et al. A luta pelo espaço: textos de sociologia urbana. Petrópolis: Vozes, 1978. p. 109-124.

${ }^{61}$ VENTURA, Zuenir. Cidade partida. São Paulo: Cia das Letras, 2003. p.13
} 
como parte da cidade. Enfim, muito embora a urbanização das favelas ${ }^{62}$ venha sendo defendida e praticada há um certo tempo, a titularidade definitiva dessas áreas para seus verdadeiros moradores somente vem encontrando solução viável após o advento do Estatuto da Cidade e da Medida Provisória no 2.220, de 04/09/2001, por intermédio dos institutos da Usucapião Especial Coletiva e da Concessão de Uso Especial para Fins de Moradia, outorgada coletivamente aos ocupantes dos imóveis.

A Constituição Federal de 1988 dedicou um capítulo específico à política urbana, elegendo o Plano Diretor como paradigma do cumprimento da função social da propriedade; sendo que deixava a desejar quanto ao aspecto da eficácia, quando remetia a fixação das diretrizes da política e a aplicação das penalidades à regulamentação em lei federal. Por conseguinte, é exatamente isso o que faz o Estatuto da Cidade, pois esta legislação outorgou ao poder público o embasamento legal para as ações dos governos locais. ${ }^{63}$

Então, compreendemos que, apesar de suas contribuições econômicas, políticas e culturais para a cidade, as favelas do Rio de Janeiro são, desde seu surgimento, na passagem para o século XX, observadas com certa preocupação. De fato, se por um lado elas vêm sendo cada vez menos percebidas como problema eminentemente sanitário ou moral; por outro, aparecem hoje na mídia como o foco transmissor da violência e da criminalidade, visto que a persistência desta representação negativa das favelas e de seus habitantes remete a sua história como objeto de diferentes modalidades de controle, notadamente por parte do poder público e das instituições sociais.

Nessa perspectiva, inúmeros estudos têm sido realizados por pesquisadores brasileiros e estrangeiros ${ }^{64}$, possibilitando-nos reconstruir esse percurso a partir dos principais aspectos que regeram e ainda regem as intervenções do Estado sobre esses espaços. De um modo geral, inobstante

62 Tomemos como exemplo, o bem-sucedido processo de urbanização ocorrido em Mata Machado, favela situada no Alto da Boa Vista, bairro do Rio de Janeiro, Assim, para Heye, Mata Machado não é uma favela "típica" carioca, no sentido utilizado pela mídia; além do mais não é a favela vertical colorida dos sambas e nem tampouco a favela espalhafatosa de crimes em manchetes, ou mesmo de miséria ostensiva. Cf. HEYE, Ana Margarete. A questão da moradia numa favela do Rio de Janeira ou como ter anthropological blues sem sair de casa. In: VELHO, Gilberto. (Coord.). O desafio da cidade: novas perspectivas da antropologia brasileira. Rio de Janeiro: Campus Ltda, 1980, p.117-142.

63 São exemplos emblemáticos de favelas que passaram por processos de Regularização Fundiária, as experiências ocorridas em Jaboatão dos Guararapes-PE, Porto Alegre-RS e Belo Horizonte-MG; cf. LEITÃO, Isolda. Uma experiência de usucapião coletivo em Jaboatão dos Guararapes-PE. In: ALFONSIN; FERNANDES, 2004, p. 145-176; SILVA, Jacqueline Severo da. Irregularidades fundiária e usucapião especial urbana: ruptura com a tradição jurídica de proteção à propriedade privada? A experiência de Porto Alegre (1989-2004). 2005. 179 f. Dissertação. (Mestrado em Planejamento Urbano e Regional) - Programa de Pós-Graduação em Planejamento Urbano e Regional da Faculdade de Arquitetura da Universidade Federal do Rio Grande do Sul, Porto Alegre, 2005; FERNANDES, Edésio. A regularização das favelas no Brasil: o caso de Belo Horizonte. In: 1998, p. 133-168.

${ }^{64}$ Cf. VALLADARES, Lícia do Prado. Passa-se uma casa: análise do programa de remoção de favelas do Rio de Janeiro. Rio de Janeiro: Zahar, 1978; SILVA, Maria Laís Pereira da. Favelas cariocas: 1930-1964. Rio de Janeiro: Contraponto, 2005; LEEDS, Anthony; LEEDS, Elizabeth. A sociologia do Brasil urbano. Rio de Janeiro: Zahar, 1978. 
as variadas abordagens, todos esses trabalhos científicos têm um eixo em comum, revelado pelo fato de indicar que a descoberta da favela pelo poder público como um "problema" surgiu mais devido ao incômodo que esses aglomerados urbanos causavam ao espaço urbano do que de uma reivindicação de seus habitantes ou mesmo de uma vontade política de universalização do acesso aos direitos básicos de cidadania.

Em 1993, foi criado pela prefeitura do Rio de Janeiro o "Programa Favela-Bairro", tendo como objetivo "integrar as favelas à cidade". Este projeto foi resultante de um processo gradativo de avaliação das dificuldades e limites das experiências utilizadas até a década anterior, principalmente devido ao fracasso e alto custo das políticas remocionistas ${ }^{65}$, bem como da necessidade de consolidar intervenções viáveis de urbanização, tais como aquelas desenvolvidas pela "Companhia de Desenvolvimento de Comunidades" (CODESCO), isso em 1988, e pelo "Projeto Mutirão", promovido pela prefeitura no início dos anos de 1980.

O Programa Favela-Bairro surgiu da percepção de que era preciso criar uma maneira de intervir nas favelas que promovesse sua integração e não mais a sua remoção, reunindo a participação de diversos órgãos e secretarias. Ressalte-se que tal mudança de orientação político-administrativa da prefeitura do Rio ganhou força com a realização dos seguintes eventos: Primeiro Seminário sobre Áreas Favelizadas, Política de Urbanização e Meio Ambiente, na oportunidade da Conferência das Nações Unidas para o Meio Ambiente e Desenvolvimento (Rio-92 ou Eco-92), realizada em 1992; como também com as discussões voltadas para a elaboração do Primeiro Plano Diretor da Cidade do Rio de Janeiro, que foi sancionado neste mesmo ano. ${ }^{66}$ Originariamente, o Programa Favela-Bairro ${ }^{67}$ é um dos subprogramas de regularização das favelas criados entre 1993-1997, sendo voltado para aquelas comunidades que possuíam entre 500 e 2.500 unidades habitacionais; além disso, era financiado, em parte, pelo Banco Interamericano de Desenvolvimento (BID), sob coordenação da Secretaria Municipal de Habitação, tendo como objetivo institucional "construir ou complementar a

65 VALLADARES, 1978.

66 Cf. PREFEITURA DO RIO DE JANEIRO. Plano Diretor Decenal da Cidade do Rio de Janeiro. Rio de Janeiro. Secretaria Municipal de Urbanismo. 1992; Municipal de Habitação, jun. 2002. Informativo Habitação: Favela-Bairro: Rio de Janeiro. Secretaria

67 Sobre o Programa Favela-Bairro, Marcelo Lopes de Souza identifica tal iniciativa como "um exemplo do que não fazer", pois, embora seja também conhecido como um programa de regularização fundiária, a prefeitura fez formalmente a opção de separar a regularização fundiária do âmbito do programa, transferindo tal competência para um Gerência de Regularização Fundiária Independente. Cf. SOUZA, Marcelo Lopes de. Problemas da Regularização Fundiária em Favelas Territorializadas por Traficantes de Drogas. In: ALFONSIN, Betânia; FERNANDES, Edésio. Direito à moradia e segurança da posse no Estatuto da Cidade: diretrizes, instrumentos e processos de gestão. Belo Horizonte: Fórum, 2004, p. 241-266. 
estrutura urbana principal (saneamento e democratização de acessos) e oferecer as condições ambientais de leitura da favela como bairro da cidade". ${ }^{68}$

Atualmente, o Rio de Janeiro vem desenvolvendo a implantação das "Unidades de Polícias Pacificadoras" (UPPs), já existindo até o presente momento 38 destas instaladas, tendo como propósitos fundamentais a segurança, cidadania e inclusão social. Contudo, vem ocorrendo inúmeros episódios que põem em dúvida a "legitimidade" dessas intervenções, visto que vem sendo verificado um certo impacto das UPPs no cotidiano dos moradores dessas favelas, incluindo a imagem destas nas relações com o conjunto da cidade. Enfim, é merecedor de reflexões os limites e as potencialidades das UPPs, considerando o seu alcance sobre o exercício da cidadania não apenas nas favelas ocupadas por essa forma de policiamento ostensivo, mas no conjunto metropolitano. ${ }^{69}$

Um aspecto relevante na discussão do tema que envolve as favelas do Rio de Janeiro diz respeito a concepção moral dos termos "favelas" e "favelados", tendo em vista que está associada ao estigma produzido historicamente em relação a estes espaços urbanos e seus habitantes, ou seja, a noção de favela enquanto espaço estigmatizante. Com efeito, ao longo do tempo, o termo "favela" vem adquirindo um caráter depreciativo, pois em volta deste espaço se construiu uma representação social envolvendo uma série de mitos relacionados à pobreza, à violência e à criminalidade, que se refletiu nas ações empreendidas pelo poder público e na consequente estigmatização de seus habitantes como pobres, violentos e marginais.

Nesse sentido, Goffman ${ }^{70}$ assevera que o estigma está relacionado com a existência de expectativas que norteiam as relações sociais, haja vista que quando entramos em contato com uma pessoa estranha, os primeiros aspectos que percebemos nesta nos possibilita prevê a sua categoria e os seus atributos, em outras palavras, a sua identidade social. Mas, sem que percebamos, transformamos essas pré-concepções em expectativas normativas, fazendo assertivas em relação aquilo que o indivíduo à nossa frente deveria ser. De fato, esperamos por uma "identidade social ideal", baseada em nossas expectativas normativas, em detrimento de sua "identidade social real". Dessa maneira, a estigmatização ocorre quando um dos grupos ou indivíduos envolvidos em uma relação social possui um ou mais atributos não previstos e considerados negativo pelos outros; logo, para Goffman, o estigma designa "a situação do individuo que está inabilitado para a aceitação social plena".

\footnotetext{
68 PREFEITURA DO RIO DE JANEIRO, 2002.

${ }^{69}$ BURGOS, Marcelo Baumann; et al. O efeito UPP na percepção dos moradores das favelas. Desigualdade \& Diversidade. Revista de Ciências Sociais da PUC - Rio, n.11, ago. /dez. p.49-48, 2011.

${ }^{70}$ GOFFMAN, Erving. Estigma: notas sobre a manipulação da identidade deteriorada. Rio de Janeiro: Zahar, 1982, p. 7 e 12.
} 
Por seu turno, Gondim ${ }^{71}$, ao analisar o morador de favela, entende que o estigma não se esgota na mera situação geográfica, pois está associado a uma condição de pobreza e a uma relação hierárquica na estrutura social, as quais permitem a sua manipulação no âmbito da política habitacional. Realmente, esse estigma relacionado à pobreza e ao crime interfere nos mais variados aspectos da vida dos moradores das favelas, como, por exemplo, a busca por empregos, a relação com a polícia ou até mesmo a simples aproximação com outras pessoas. Então, objetivando amenizar esse estigma, a categoria "comunidade" 72 parece exteriorizar, tanto para os representantes do poder público quanto para os moradores diretamente envolvidos pelo processo de estigmatização ${ }^{73}$, uma alternativa simbólica pertinente. Assim, em lugar da terminologia "favela", a expressão "comunidade" parece ser uma opção mais viável, até porque encontra-se em consonância com a forma atual com que os órgãos governamentais e as organizações da sociedade civil se referem a esses espaços urbanos. De modo similar, a própria prefeitura do Rio de Janeiro vem adotando esse termo como a forma politicamente correta de fazer alusão a essas localidades e seus moradores.

Outrossim, nessa discussão é de extrema relevância o desenvolvimento de uma reflexão crítica a respeito dos possíveis fatores motivadores da criminalidade, a partir da miséria, desigualdade e exclusão social, verdadeiro paradoxo da realidade social brasileira, com amplos reflexos na cidade do Rio de Janeiro. Nessa conjuntura, em praticamente um século o Brasil transformou-se em uma economia industrial, ao lado de países como Japão, Filândia, Coreia e Noruega. Mas, analisando a distribuição de renda nestes 100 anos, constata-se que os governantes deste período, segundo o Instituto Brasileiro de Geografia e Estatística (IBGE), não alcançaram uma efetiva justiça social, que é o objetivo final de toda nação moderna; por outro lado, não se pode deixar de admitir que ocorreram importantes transformações no Brasil nestas últimas décadas.

\footnotetext{
${ }^{71}$ GONDIM, Linda Maria. A manipulação do estigma de favelado na política habitacional do Rio de Janeiro. Revista de Ciências Sociais da UFC, v.12/13, n.1-2, Fortaleza, 1982.

72 Encontramos em Birman uma outra forma de expressão que pode ter o uso do termo "comunidade", pois além da intenção de evitar mencionar a identificação, por aquele que fala, sobre o lugar estigmatizante da favela; pode também exteriorizar as intenções de identificar a favela com o ideal de harmonia e de tradição, de salientar as experiências pessoais positivas, associando-as aos lugares de ocorrência e, ainda, de mostrar "o outro lado" desses territórios, que se revela contrário e mesmo antagônico à visão totalizante que os identifica "de fora". Cf. BIRMAN, Patrícia. Favela é comunidade. In: SILVA, Luiz Antônio Machado. (Org.). Vida sob cerco: violência e rotina nas favelas do Rio de Janeiro. Rio de Janeiro: Nova Fronteira, 2008; BAUMAN, Zygmunt. Comunidade: a busca por segurança no mundo atual. São Paulo: Zahar, 2004. p.7 et seq.

${ }^{73}$ Com relação ao processo de estigmatização que diz respeito a expressão "favela", tomemos como contraexemplo o trabalho da Lia de Mattos Rocha, que desenvolveu um estudo na Favela do Pereirão, no Rio de Janeiro, a partir da particularidade desta favela ser diferente das outras, não apenas por sua tranquilidade e pacificação, mas por ter uma população relativamente pequena, dispondo de duas formas de organização atuantes: uma associação de moradores e uma ONG. Cf. ROCHA, Lia de Mattos. Uma favela "diferente das outras?": rotina, silenciamento e ação coletiva na Favela do Pereirão. Rio de Janeiro: FAPERJ/Quartet, 2013.
} 
Com efeito, de 1997 até os dias atuais, o país vem aumentando o Produto Interno Bruto (PIB), havendo um crescimento significativo dos domicílios com variados eletrodomésticos, como também a frota de veículos vem tendo uma grande elevação; contudo, a taxa de miséria permaneceu praticamente inalterada. Segundo o IBGE, a pobreza alcança cerca de 54 milhões de pessoas, ou seja, quase 32\% da população brasileira. Sem dúvida, é um número significativo se comparado a população da Colômbia, com 40 milhões de habitantes; sendo que essa pobreza, no Brasil, distribui-se de forma desigual, pois os dados do IBGE registra que o Nordeste abriga $50.9 \%$ de pobres, enquanto o sudeste 17.8\%. Porém, é necessário ressaltar que o objetivo deste trabalho não é aprofundar-se em questões socioeconômicas da realidade brasileira, e sim desenvolver uma reflexão sobre a exclusão social e seus efeitos na cidade do Rio de Janeiro.

A partir das considerações apresentadas inicialmente deste tópico, é possível perceber que o estigma da desigualdade social tem origem histórica na América Latina, com o processo exploratório de colonização. ${ }^{74}$ No Brasil, foram as metrópoles que mais sofreram com o rendimento econômico baixo, visto que isso gerou inúmeros problemas sociais, afetando especialmente os jovens ${ }^{75}$, que ficavam e ainda ficam expostos ao desemprego e à violência. Nesse sentido, afirma Moura ${ }^{76}$ que o país tem de investir amplamente em educação, saúde e infraestrutura sem, evidentemente, esquecer-se da segurança. Todavia, é necessário que cada Estado tenha uma estratégia de longo prazo, redefinindo o seu papel no âmbito da sua dimensão na economia do Brasil, com a consequente aplicação com eficiência dos recursos públicos. Indiscutivelmente, é possível afirmar que, diante do quadro social exposto, existe uma certa tendência para que as carências sociais aumentem a atração pelas soluções imediatas e ilegais, sobretudo para os jovens.

A cidade do Rio de Janeiro é possuidora de problemas sociais peculiares, sendo pertinente realizar algumas reflexões sobre as distorções advindas principalmente da desigualdade social presente no Brasil. De fato, considerando o Estado do Rio de Janeiro como um todo, neste início de

\footnotetext{
74 OSÓRIO, 2004, p. 17 et seq.

$75 \mathrm{Na}$ favela, por exemplo, os jovens convivem cotidianamente com a precariedade da infraestrutura, a baixa qualidade da moradia, o convívio com a violência (do tráfico ou policial), as dificuldades de inserção social e econômica, o estigma etc. Desse modo, eles vivem sob outro código de valores, tendo suas próprias estratégias de sobrevivência que tem na favela elemento fundamental; por consequenite, a favela é um produto cultural daqueles que não conseguiram resolver seus problemas de moradia e de localização na cidade, segundo as regras de mercado. Além de que, o viver nas favelas é também condiciona e compromete a formação desses jovens por intermédio da presença do tráfico. Cf. RIBEIRO, Manoel. As favelas têm seus próprios códigos. In: KONDER, Leandro et al. Encontros temáticos: cultura, poder e movimento social. Rio de Janeiro: FAPERJ/SESC/UNESCO, 2004. p.61-62.

76 MOURA, Marcelo. Grandes metrópoles sofreram mais com o baixo crescimento. O Globo. Rio de Janeiro, 10 ago. 2003, p.40.
} 
século vem sendo verificado significativas elevações da pobreza e indigência. ${ }^{77}$ Além do mais, a distância social na cidade do Rio de Janeiro, entre a favela e o asfalto $^{78}$, é cinco vezes maior do que a proximidade física. Segundo dados do IBGE, em geral, a renda do morador do asfalto é o quíntuplo do habitante da favela, sem levar em consideração a Lagoa, a Barra, a Gávea etc. De maneira que essa distância se exterioriza mais na medida em que os bairros se aproximam, sendo esse o primeiro sinal de desigualdade social capaz de gerar múltiplos efeitos. ${ }^{79}$ Realmente, o crescente abismo entre os pobres e os ricos projeta os dois lados de uma mesma cidade que convive com uma desigualdade que pode chegar a 700\% da renda média entre os moradores da Lagoa e do Jacarezinho. ${ }^{80}$

Portanto, diante de uma realidade tão complexa, instalou-se a denominada crise urbana, principalmente devido a ausência de uma adequada política habitacional, pois o que se constata é a falta de uma efetiva política pública de moradia para a população de baixa renda. Na época atual, segundo dados do Ministério das cidades ${ }^{81}$, o déficit habitacional brasileiro é estimado em aproximadamente 5.546 .000 domicílios, abrangendo pessoas em situação de habitação precária, coabitação familiar, ônus excessivo com aluguel e adensamento excessivo de moradores em domicílios alugados. Nessa conjuntura, considerando que $91 \%$ dos brasileiros vivem em cidades e, em boa parte, $40 \%$ em capitais e periferias, inevitavelmente o resultado é a disseminação de espaços irregulares nas áreas urbanas. Para se ter uma ideia, segundo dados oficiais do Censo de 2010, coletados pelo IBGE, existem 763 favelas na cidade do Rio de Janeiro; ou seja, cerca de $22 \%$ da população desta cidade mora em favelas, sendo a capital fluminense o município com o maior número de moradores favelados do Brasil, aproximadamente 1.393.314 habitantes. $^{82}$

Assim sendo, compreendemos que a desigualdade, a indigência e a ausência de adequadas políticas públicas para habitação forma um círculo vicioso que, notadamente desde a década de 70 do

\footnotetext{
77 POBREZA AUMENTOU NO RIO DE 1999 A 2001. O Globo, Rio de Janeiro, 05 out. 2002, p.31.

78 Encontramos importantes contribuições para a compreensão das complexas relações entre a favela e o asfalto no trabalho de Rocha, a partir de uma pesquisa na favela Santa Marta, envolvendo atividades de organização dos moradores no sentido de promover melhorias material e simbólica; havendo assim toda uma articulação entre o trabalho comunitário do morro com a associação dos moradores. Assim, essa obra é útil no entendimento da história mais recente das favelas cariocas, onde há o enfrentamento das dificuldades, desde as carências materiais, de acesso aos serviços públicos, da estigmatização associada a pobreza, até a atração espacial e social exercida pelo morro para a entrada do comércio de drogas, com sua sequela de violência; ademais, esse trabalho é fundamental para o desenvolvimento democrático da cidade e o encaminhamento de soluções para melhoria das condições de vida materiais, simbólicas e de acesso à educação das populações residentes nas favelas. ROCHA, Adair. Cidade cerzida: a costura da cidadania no Morro Santa Marta. 3.ed. Rio de Janeiro: Pallas/PUC-Rio, 2012.

79 O ABISMO SOCIAL. O Globo, Rio de Janeiro, 28 jul. 2002, p.19.

80 NERI, Marcelo. Abismo crescente entre a população. O Globo, Rio de Janeiro, 12 out. 2003, p. 29.

${ }^{81}$ BRASIL. Ministério das Cidades. Secretaria Nacional de Habitação. Déficit habitacional no Brasil, 2008. Brasília: Ministério das Cidades, 2011.

82 FAVELAS na cidade do Rio de Janeiro. In: WIKIPÉDIA: a Enciclopédia Livre. [S.I.:s.n.], 2014. Disponível em: <http: //pt.wikipedia.org/wiki/Favelas_na_cidade_do_Rio_de_Janeiro>. Acesso em: 16 out. 2014.
} 
século passado, vem resultando no inevitável aumento da favelização da cidade. Registre-se que em 2001 foi observada a "invasão silenciosa das favelas", revelando, segundo o IBGE, no mínimo, o surgimento de uma nova favela com mais de 50 casas a cada mês no município, isso nos últimos 10 anos. ${ }^{83}$ Ademais, uma vez constatado o grave problema social do Brasil, é igualmente pertinente salientar que a população cresceu $1,64 \%$ ao ano, segundo o IBGE; enquanto que, nos aglomerados subnormais, houve um crescimento de 4,32\%. Desse modo, o Brasil das favelas tem aproximadamente 6,5 milhões de habitantes, ou seja, 3,84\% da população do país vive em habitação subnormal. Evidentemente, tal fenômeno tem várias causas com tendência ao agravamento, destacando-se entre elas: a falta de investimento em habitação; a migração desordenada; o desemprego; a indigência mínima; e, principalmente, a ausência de políticas públicas por parte dos setores competentes da administração pública brasileira, seja federal, estadual ou municipal. ${ }^{84}$

De maneira que as favelas não param de crescer de forma desordenada, notadamente devido a ausência do Estado, transformando grandes áreas das cidades em espaços fora dos ditames da legalidade. Por conseguinte, a criminalidade tira proveito dessa realidade urbana, instalando seu poder e comprometendo a rotina precária e humilde dos trabalhadores. Dessa forma, as autoridades do Estado do Rio de Janeiro e a população, em especial, estão diante de uma questão de alta complexidade; até porque durante praticamente um século o poder público não deu a devida atenção a problemática das favelas. Atualmente, observa-se que tal situação está longe de ser solucionada, devido a crescente tendência de favelização da população que, por falta de um planejamento urbano adequado, prolifera de forma descontrolada nas grandes cidades brasileiras, notadamente na Cidade Maravilhosa. Registre-se que esse fato foi confirmado pelo Ministro das Cidades, na oportunidade em que, no Plenário da ONU, declarou que, de 1999-2001, o número de favelas cresceu 150\% no Brasil, sendo isto o resultado de anos de descaso do Estado com a questão urbana. ${ }^{85}$

Em resumo, tudo isso exterioriza os grandes transtornos existentes no âmbito do ordenamento do espaço público no Rio de Janeiro, acrescentando-se, também, o fato da rapidez que tem o crescimento das favelas em direção ao "asfalto"; haja vista que a proximidade de diferentes culturas gera complexas consequências no campo econômico, na infraestrutura, na expectativa de vida, na violência/criminalidade etc. Por conseguinte, o resultado de todo esse processo de degradação é que aproximadamente $20 \%$ dos bairros do Rio de Janeiro estão dominados pela violência do narcotráfico, que escolhe dia e horário para fechar escolas, comércios, hospitais, entre outros estabelecimentos, controlando até mesmo os transportes que podem ou não circular nessas

\footnotetext{
${ }^{83}$ A INVASÃO SILENCIOSA DAS FAVELAS. O Globo, Rio de Janeiro, 28 jan. 2001, p. 18.

${ }^{84}$ A EXPLOSÃO DAS FAVELAS. O Globo, Rio de Janeiro, 09 mai. 2004, p.3.

${ }^{85}$ FAVELIZAÇÃO E IMPOTÊNCIA. O Globo, Rio de Janeiro, 01 mai. 2004, p. 3.
} 
comunidades. De modo igual, as zonas de conflito definem o entorno da Avenida Brasil, Linhas Amarela e Vermelha como uma verdadeira Faixa de Gaza, tendo em vista que policiais e traficantes do Complexo da Maré constantemente estão se defrontando ${ }^{86}$, colocando em risco os usuários que utilizam vias que dão acesso a importantes regiões da cidade. ${ }^{87}$

Indiscutivelmente, a realidade vivenciada no Rio de Janeiro representa uma verdadeira bomba-relógio, que para Gilberto Velho ${ }^{88}$ tem sua origem não apenas na pobreza, mas na disparidade dos altos padrões de vida e na indigência, bastante expressivos em razão do grande abismo social. Para esse autor, essa desigualdade tem desencadeado uma grave crise de valores, na qual os indivíduos buscam suas próprias identidades ${ }^{89}$, não mais aceitando viver das sobras dos ricos. Logo, estamos diante de uma série de fatores que predispõem práticas de comportamentos violentos, como bem enfatiza Velho:

Na ausência de um sistema de reciprocidade minimamente eficaz, se expressa uma desigualdade associada e produtora de violência. A impossibilidade de acessos da grande maioria das camadas populares, a bem de valores largamente publicizados, através da mídia e da cultura de massas, em geral, acirra a tensão e o ódio sociais. A inadequação de meios legítimos para realizar essas aspirações fortalece o mundo do crime. Esboroam-se as escalas de valores tradicionais que, de algum modo, legitimavam certas diferenças e, até certo ponto, a própria desigualdade. [...] a natureza do individualismo na sociedade brasileira vem assumindo características tais que a tornam palco de um capitalismo voraz com uma dimensão selvagem, relegando a segundo plano as referidas preocupações com equidade e reforma social.

De fato, nos dias atuais é possível perceber a identificação de alguns canais de mobilidade social, sendo que eles estão, em princípio, vinculados a ideologias individualistas, compatíveis com o paradigma dominante da racionalidade instrumental, com pouco ou nenhum compromisso com projetos de reciprocidade e justiça social.

\footnotetext{
86 Encontramos uma importante abordagem sobre a "violência urbana" a partir de tiroteios envolvendo traficantes de drogas e policiais no trabalho de Mariana Cavalcanti, quando esta autora levanta a hipótese de que a reprodução e a construção social do espaç̧o da favela são atravessadas por dinâmicas e rotinas em grande parte imposta pela ação do tráfico. Cf. CAVALCANTI, Mariana. Tiroteios, legibilidade e espaço urbano: notas etnográficas de uma favela carioca. DILEMAS - Revista de Estudos de Conflito e Controle Social NECVU/IFCS/UFRJ, v.1, jul. /ago. /set. 2008, p. 35-59.

87 VIOLÊNCIA DE VOLTA À FAIXA DE GAZA. O Globo, Rio de Janeiro, 25 mai. 2005, p. 16.

88 VELHO, Gilberto. Uma bomba-relógio. O Globo, Rio de Janeiro, 07 out. 2003, p. 17.

${ }^{89}$ Com relação à perspectiva da "identidade", atualmente vem sendo inserida a ideia de "cultura do varejo", a partir do nicho das tribos, onde trabalha-se com quaisquer faixas etária, gênero ou renda. Nesse estabelecimento, encontram-se pessoas convivendo com seus "semelhantes", comprando os signos que thes dão identidade: a roupa, o livro, $C D$, os móveis e objetos de decoração etc.; enfim, todos esses produtos Ihes dizem respeito à identidade da sua tribo, a forma de posicionar-se na sociedade contemporânea. Cf. RIBEIRO, Manoel. As favelas têm seus próprios códigos. In: KONDER, Leandro et al. Encontros temáticos: cultura, poder e movimento social. Rio de Janeiro: FAPERJ/SESC/UNESCO, 2004. p. 60.
} 


\section{CONSIDERAÇÕES FINAIS}

Ao término deste texto, compreendemos que as funções sociais da cidade estarão sendo desenvolvidas integralmente quando houver redução das desigualdades sociais, promoção da justiça social e melhoria da qualidade de vida urbana. Com efeito, enquanto estas pessoas não tiverem acesso à moradia, transporte público, saneamento básico, saúde, educação, segurança, trabalho digno etc., não há como reconhecer que a cidade esteja atendendo à sua função social. Além disso, é importante salientar que não é por falta de planos ou de legislações urbanísticas que as cidades crescem de modo predatório, haja vista que um abundante aparato regulatório normatiza a produção do espaço urbano no Brasil, com rigorosas leis de zoneamento, exigentes legislações de parcelamento do solo, códigos de edificações, entre outros instrumentos que são formulados por corporações profissionais, que desconsideram a condição de ilegalidade em que vive grande parte da população urbana brasileira em relação à moradia e à ocupação da terra, demonstrando tudo isso que a exclusão social passa pela lógica da aplicação discriminatória da lei.

Nesse contexto, é pertinente esclarecer que a moradia é um direito fundamental introduzido o rol do art. 60 da CF/88, sendo reiterado pela Emenda Constitucional no 26/2000; além de que já era previsto em vários tratados, convenções, pactos e agendas internacionais. De maneira que é pertinente destacar a relevância que tem o direito à moradia digna e adequada, tendo em vista que este direito fundamental concorre para que seja alcançado o objetivo maior, que é assegurar uma boa qualidade de vida às gerações presentes e futuras.

Desde a década de 70 do século XX que alguns municípios vêm tentando investir nas favelas, reconhecendo sua existência como parte da cidade. Todavia, muito embora a urbanização dessas comunidades venha sendo defendida e praticada há tempo, a titularidade definitiva dessas áreas para seus verdadeiros moradores somente vem encontrando solução viável após o advento do Estatuto da Cidade e da Medida Provisória no 2.220, de 04/09/2001, por intermédio dos institutos da Usucapião Especial Coletiva e da Concessão de Uso Especial para Fins de Moradia, outorgada de forma coletiva.

Outrossim, entendemos que é preciso propugnar por mudanças capazes de levar a urbanização para o âmbito de políticas públicas pluridimensionais, objetivando ampliar a inclusão da massa empobrecida na cidadania plena, o que implicará melhor acesso aos bens e serviços socialmente constituídos, como educação, moradia, saúde e meios de consumo coletivo (água, esgoto, transporte etc.). No caso específico da cidade do Rio de Janeiro, programas como os que foram destacados no decorrer deste estudo são ações adequadas para a equalização do problema da exclusão das redes de infraestrutura e de equipamentos sociais; além do mais, eles abrem espaço para 
intervenções físico-urbanísticas que mudam a qualidade de inserção nos assentamentos das cidades, por meio de práticas que possibilitam acessos a espaços públicos para o convívio e a sociabilidade.

Foi igualmente verificado que o Estado vem reconhecendo a sua limitada autossuficiência em matéria urbanística, incentivando a ação privada nesse campo, inclusive acenou em duas das diretrizes do art. 2ำ do Estatuto da Cidade sobre essa sua limitação, buscando a cooperação da iniciativa privada. Por um lado, previu-se que no processo de urbanização vigorará o princípio da cooperação entre os governos, a iniciativa privada e os demais setores da sociedade; já por outro, estabeleceu-se que na promoção de empreendimentos e atividades relativas ao processo de urbanização, incidirá o princípio de isonomia de condições para os agentes públicos e privados. Em suma, tais dispositivos legais demonstram a preocupação em ressalvar-se a necessidade de atendimento ao interesse social.

No decorrer do processo histórico e social de urbanização, as favelas proliferaram no Rio de Janeiro em uma época em que os controles urbanísticos formais eram cada vez mais acentuados, sendo que elas eram pouco afetadas por eles, sendo isto explicado pelo fluxo migratório que então se verificava e que, por si só, já comprometia a efetivação de qualquer ação coercitiva por parte do poder público; além de que essa mesma mão-de-obra, de custo baixo, era necessária à indústria, ao comércio e à burguesia em geral, no acúmulo de capital. Na época atual, é possível verificar que as áreas metropolitanas brasileiras são conclusões espaciais delineadas da formação social brasileira, exteriorizando a coerência e as contradições dos sistemas econômico, institucional e ideológico prevalecentes no país. Portanto, constatamos que, apesar de suas contribuições econômicas, políticas e culturais para a cidade, as favelas do Rio de Janeiro são observadas de forma preocupante. De fato, se por um lado elas vêm sendo cada vez menos percebidas como problema eminentemente sanitário ou moral; por outro, aparecem hoje na mídia como o foco transmissor da violência e da criminalidade, visto que a persistência desta representação negativa das favelas e de seus habitantes remete a sua história como objeto de diferentes modalidades de controle, notadamente por parte do poder público e das instituições sociais.

Sem dúvida, é fato público e notório que as favelas não param de crescer de forma desordenada, notadamente devido a ausência do Estado, transformando grandes áreas da cidade em espaços fora dos ditames da legalidade. Por sua vez, a criminalidade tira proveito desta situação urbana, instalando seu poder e comprometendo a rotina precária e humilde dos trabalhadores. De modo que as autoridades do Estado do Rio de Janeiro e a população, em especial, estão diante de uma preocupante problemática: as favelas, que vem se desenvolvendo há mais de um século, sendo que o poder público não deu a devida atenção. Em síntese, tudo isso tem revelado grandes 
transtornos para o ordenamento do espaço público no Rio de Janeiro, acrescentando-se, também, o fato da rapidez que tem o crescimento das favelas em direção ao "asfalto", pois a proximidade de diferentes culturas desencadeia uma série de consequências no campo econômico, na infraestrutura, na expectativa de vida, na violência/criminalidade etc.

Concluímos também que o cenário da cidade do Rio de Janeiro não é diferente de outras grandes cidades do país e do mundo, mas guarda particularidades que se tem de levar em consideração, principalmente com relação à exclusão social, tendo em vista que representa um problema de alta complexidade, que tem sua origem não apenas na pobreza, mas na disparidade dos altos padrões de vida e na indigência, aspectos estes bastante expressivos em razão da imensa desigualdade social existente. Evidentemente que esta iniquidade trata-se de um problema histórico, sendo que se acredita ser igualmente um fator determinante que, aliado a outros, como miséria, indigência, desemprego, falta de oportunidades, família e educação, são fortes aspectos desencadeadores da criminalidade.

Em geral, as metrópoles foram as que mais sofreram com a desigualdade social e a indigência, ficando os jovens expostos ao desemprego e à violência. Logo, compreendemos que o país tem de investir vigorosamente em educação, saúde, infraestrutura e segurança; além disso, é necessário que os Estados tenham suas estratégias próprias de longo prazo, redefinindo seus papeis no âmbito da dimensão econômica do país, com a consequente aplicação eficiente dos recursos públicos.

Foi também observada a necessidade de uma compreensão das favelas como sendo parte da estratégia de sobrevivência das populações mais carentes, que não têm possibilidade de resolver o seu problema da moradia, sob as regras do mercado. Realmente, a política capaz de produzir resultados satisfatórios no âmbito do problema da moradia passa por ações de regularização fundiária, haja vista que quando se regulariza a propriedade nas favelas e periferias, imediatamente ocorre a capitalização dessas populações. Em outras palavras, os atuais ocupantes ganham possibilidade de acesso ao crédito, pois existe uma garantia real para ser oferecida; de forma que a favela tem sido um grande instrumento de inserção dessas populações na cidade e na economia urbana. Ademais, a percepção das melhorias de vida da comunidade, com novas conquistas públicas e sociais, associadas ao desenvolvimento social e familiar, que permite ao morador construir sua casa de alvenaria, comprar eletrodomésticos para seu uso diário, ter emprego, colocar seus filhos na escola etc., passa a ser mais associada a conquista de direitos objetivamente.

Enfim, esperamos que este texto venha a contribuir para o desenvolvimento democrático das funções sociais da cidade, a partir do encaminhamento de soluções para a melhoria das condições de vida, bem como do acesso aos direitos sociais imprescindíveis para as populações residentes nas 
favelas. De igual modo, é também importante o desenvolvimento contínuo de uma consciência comunitária e cidadã, não apenas das populações das comunidades, internamente, mas do conjunto da cidade e da sociedade como um todo.

\section{REFERÊNCIAS}

A INVASÃO SILENCIOSA DAS FAVELAS. O Globo, Rio de Janeiro, 28 jan. 2001, p. 18.

A EXPLOSÃO DAS FAVELAS. O Globo, Rio de Janeiro, 09 mai. 2004, p.3.

ABREU, Maurício de A. A Evolução Urbana do Rio de Janeiro. Rio de Janeiro: IPLANRIO, 1997.

ACSELRAD, Henri; MELLO, Cecília Campelo do Amaral; BEZERRA, Gustavo das Neves. Cidade, ambiente e política: problematizando a Agenda 21 local. Rio de Janeiro: Garamond, 2006.

ARENDT, Hannah. Entre o passado e o futuro. Trad. Mouro W. Barbosa de Almeida. São Paulo: Perspectiva, 1972.

As origens do totalitarismo. Trad. Roberto Raposo. 2. ed. Rio de Janeiro: Documentário, 1976, v.1.

As origens do totalitarismo. Trad. Roberto Raposo. 2. ed. Rio de Janeiro: Documentário, 1976, v.2.

The rights of man, What are they? Modern Review. New York, 3(1), 1949.

A condição humana. 11.ed. Trad. Roberto Raposo. Rio de Janeiro: Forense Universitária, 2010.

BALDEZ, M. Solo urbano, reforma urbana, propostas para a Constituinte. Rio de Janeiro: Fase, 1986.

BARRETTO, Vicente. Ideologia e política no pensamento de José Bonifácio de Andrade e Silva. Rio de Janeiro: Zahar, 1977.

BAUMAN, Zygmunt. Vidas desperdiçadas. Rio de Janeiro: Zahar, 2004

Comunidade: a busca por segurança no mundo atual. São Paulo: Zahar, 2004.

BIRMAN, Patrícia. Favela é comunidade. In: SILVA, Luiz Antônio Machado. (Org.). Vida sob cerco: violência e rotina nas favelas do Rio de Janeiro. Rio de Janeiro: Nova Fronteira, 2008.

BLAY, E. A. Planejar para quem? (ou a reprodução de favelas nas cidades paulistas. In: et al. A luta pelo espaço: textos de sociologia urbana. Petrópolis: Vozes, 1978.

BOGÉA, M. Cidade errante: arquitetura em movimento. São Paulo: SENAC, 2009.

BRASIL. Mapa de Injustiça Ambiental e Saúde no Brasil. 2010. Disponível em: http://www.conflitoambiental.icict.fiocruz.br. Acesso em: 2 abr.2011. 
Presidência da República. Ministério das Relações Exteriores. Relatório Nacional Brasileiro: Cúpula Mundial para o Desenvolvimento Social. Copenhague/Brasília, fev., 1995.

Ministério das Cidades. Secretaria Nacional de Habitação. Déficit habitacional no Brasil, 2008. Brasília: Ministério das Cidades, 2011.

BUARQUE, Cristovão. O colapso da modernidade brasileira: e uma proposta alternativa. 5.ed. Rio de Janeiro: Paz e Terra, 1991.

BURGOS, Marcelo Baumann; et al. O efeito UPP na percepção dos moradores das favelas. Desigualdade \& Diversidade. Revista de Ciências Sociais da PUC - Rio, n.11, ago. /dez. p.49-48, 2011.

BURSZTYN, M.; ARAÚJO, C. H. Da utopia à exclusão: vivendo nas ruas em Brasília. Rio de Janeiro: Garamond, 1997.

BURTIN-VINHOLES, S. Dicionário francês-português, português-francês. 40. ed. São Paulo: Globo, 2003.

CASTEL, Robert. De I' indigence à I' exclusion, la deafiliation: Precarité du trovail et vulnérabilité relationnelle. In: DONZELOT, J.; ROMAN, J. Face à l'exclusion: lemodele francais. Paris: Esprit 1991.

WANDERLEY, Luis Eduardo W.; BELFIORE-WANDERLEY, Mariangela. Trad. Cleisa Moreno Maffei Rosa; Mariangela Belfiore-Wanderley. Desigualdade e a questão social. 3.ed. São Paulo: EDUC, 2010.

CASTRO, Josué. A geografia da fome. São Paulo: Paz e Terra, 1976. 2010.

Geografia da fome: o dilema brasileira - pão ou aço. 10.ed. Rio de Janeiro: Civilização Brasileira,

DANTAS, M. G. A. Planejamento Urbano \& Zoning: flexibilidade do modelo de zoning para a competitividade das cidades. João Pessoa: UFPB, 2003.

FAVELAS na cidade do Rio de Janeiro. In: WIKIPÉDIA: a Enciclopédia Livre. [S.I.: s.n.], 2014. Disponível em: <http: //pt.wikipedia.org/wiki/Favelas_na_cidade_do_Rio_de_Janeiro>. Acesso em: 16 out. 2014.

FAVELIZAÇÃO E IMPOTÊNCIA. O Globo, Rio de Janeiro, 01 mai. 2004, p. 3.

CAVALCANTI, Mariana. Tiroteios, legibilidade e espaço urbano: notas etnográficas de uma favela carioca. DILEMAS - Revista de Estudos de Conflito e Controle Social - NECVU/IFCS/UFRJ, v.1, jul. /ago. /set. 2008.

FERNANDES, Edésio. Direito do urbanismo: entre a cidade legal e a cidade ilegal. In: (Org.). Direito urbanístico. Belo Horizonte: Del Rey, 1998.

A regularização de favelas no Brasil: o caso de Belo Horizonte. In: (Org.). Direito Urbanístico. Belo Horizonte: Del Rey, 1998.

GUIMARÃES, A. P. As favelas do Distrito Federal. Revista Brasileira de Estatística, v.14, n. 51, p. 250255, jul. /set. 1953.

GOFFMAN, Erving. Estigma: notas sobre a manipulação da identidade deteriorada. Rio de Janeiro: Zahar, 1982. 
GONÇALVES, Rafael Soares. Favelas do Rio de Janeiro: história e direito. Rio de Janeiro: Pallas/PUC-Rio, 2013.

GONDIM, Linda Maria. A manipulação do estigma de favelado na política habitacional do Rio de Janeiro. Revista de Ciências Sociais da UFC, v.12/13, n.1-2, Fortaleza, 1982.

GOUVÊA, L.A. Biocidade: .... São Paulo: Nobel, 2002.

HEYE, Ana Margarete. A questão da moradia numa favela do Rio de Janeira ou como ter anthropological blues sem sair de casa. In: VELHO, Gilberto. (Coord.). O desafio da cidade: novas perspectivas da antropologia brasileira. Rio de Janeiro: Campus Ltda, 1980.

HOUAISS, Antônio; VILLAR, Mauro de Salles. Dicionário Houaiss da Língua Portuguesa. Rio de Janeiro: Objetiva, 2001.

IBCA - Sovereign Comparator Ratings-Rapid Response. Disponível em: <http://rru.worldbank.org/Documens/Toolkits/Highways/pdf/.../E24.pdf>. Acesso em: 29 mar. 2012.

LAGO, Luciana Corrêa do. Desigualdades e segregação na metrópolis: o Rio de Janeiro em tempo de crise. Rio de Janeiro: Revan, 2000.

LEEDS, Anthony; LEEDS, Elizabeth. A sociologia do Brasil urbano. Rio de Janeiro: Zahar, 1978.

LEITÃO, Isolda. Uma experiência de usucapião coletivo em Jaboatão dos Guararapes-PE. In: ALFONSIN; FERNANDES, 2004

LEN, Doyal; GOUGH, lan. A theory of human need. London: palgrave, 1991.

MARICATO, E. As ideias fora do lugar e o lugar fora das ideias: planejamento urbano no Brasil. In: ARANTES, O; VAINER, C. A cidade do pensamento único: desmanchando consensos. 5. ed. Petrópolis: Vozes, 2009.

MARINS, Paulo César G. História da vida privada no Brasil. 3.ed. São Paulo: Cia das Letras, 1998.

MARSHALL, T. H. Citizenship and social class. New York: Anchor Books, 1965.

MARX, Karl; ENGELS, Friedrich. O manifesto do partido comunista. 10.ed. Trad. Marco Aurélio Nogueira; Leandro Konder. Petrópolis: Vozes, 2000

MEDINA, Carlos Alberto. A favela e o demagogo. São Paulo: Martins Fontes, 1964.

MOREIRA, C. C. A cidade contemporânea: entre a tabula rasa e a preservação - cenários para o Porto do Rio de Janeiro. São Paulo: UNESP, 2004.

MOURA, Marcelo. Grandes metrópoles sofreram mais com o baixo crescimento. O Globo. Rio de Janeiro, 10 ago. 2003.

MUMFORD, L. A cidade na história: suas origens, transformações e perspectivas. Trad. Neil R. da Silva. 5 ed. São Paulo: Martins Fontes, 2008. 
A cultura das cidades. Trad. Neil R. da Silva. Belo Horizonte: Itatiaia, 1961.

NASCIMENTO, Elimar Pinheiro do. Dos excluídos necessários aos excluídos desnecessários. In. BURSZTYN. No meio da rua: nômades, excluídos e viradores. 2. ed. Rio de Janeiro: Garamond, 2003.

NERI, Marcelo. Abismo crescente entre a população. O Globo, Rio de Janeiro, 12 out. 2003, p. 29.

O ABISMO SOCIAL. O Globo, Rio de Janeiro, 28 jul. 2002, p.19.

OSÓRIO, Letícia Marques. Direito à moradia adequada na América Latina. In: ALFONSIN, Betânia; FERNANDES, Edésio. (Orgs.) Direito à moradia e segurança da posse no Estatuto da Cidade: diretrizes, instrumentos e processos de gestão. Belo Horizonte: Forum, 2004.

PAUGAM S. La disquelification sociale: essai sur la nouvelle parvrete. 2 ed. Paris: PUF, 1993.

POBREZA AUMENTOU NO RIO DE 1999 A 2001. O Globo, Rio de Janeiro, 05 out. 2002.

PREFEITURA DO RIO DE JANEIRO. Plano Diretor Decenal da Cidade do Rio de Janeiro. Rio de Janeiro. Secretaria Municipal de Urbanismo. 1992.

Informativo Habitação: Favela-Bairro: Rio de Janeiro. Secretaria Municipal de Habitação, jun. 2002.

RIBEIRO, Manoel. As favelas têm seus próprios códigos. In: KONDER, Leandro et al. Encontros temáticos: cultura, poder e movimento social. Rio de Janeiro: FAPERJ/SESC/UNESCO, 2004.

ROCHA, Adair. Cidade cerzida: a costura da cidadania no Morro Santa Marta. 3.ed. Rio de Janeiro: Pallas/PUC-Rio, 2012.

ROCHA, Lia de Mattos. Uma favela "diferente das outras? ": rotina, silenciamento e ação coletiva na Favela do Pereirão. Rio de Janeiro: FAPERJ/Quartet, 2013.

ROGERS, Garry. What is special about social exclusion approach? In: ROGES; GORE; FIGUEIREDO, 1995.

SCHIMIDT, Benício; FARRET, Ricardo. A questão urbana. Rio de Janeiro: Zahar, 1986.

SEN, Amartya. Desenvolvimento como liberdade. Trad. Laura Teixeira Motta. São Paulo: Cia. das Letras, 2000.

SILVA, F. Recuperação de mais-valias fundiárias urbanas na América Latina: debilidade na implementação, ambiguidades na interpretação. (Tese de Doutorado) São Paulo: FAUUSP, 1999.

SILVA, J. C. A. Favelas e meio ambiente urbano. In: DALLARI. A. A.; DI SARNO, D. C. L. (coords). Direito urbanístico e ambiental. 2. ed. Belo Horizonte: Fórum, 2011.

SILVA, Jacqueline Severo da. Irregularidades fundiária e usucapião especial urbana: ruptura com a tradição jurídica de proteção à propriedade privada? A experiência de Porto Alegre (1989-2004). 2005. 179 f. Dissertação. (Mestrado em Planejamento Urbano e Regional) - Programa de Pós-Graduação em 
Planejamento Urbano e Regional da Faculdade de Arquitetura da Universidade Federal do Rio Grande do Sul, Porto Alegre, 2005.

SILVA, Maria Laís Pereira da. Favelas cariocas: 1930-1964. Rio de Janeiro: Contraponto, 2005.

SMOLKA, M. Velhas novidades na agenda do Banco mundial para a política urbana nos anos 1990. In: GONÇALVES, M. F. (Org). O novo Brasil urbano. Porto Alegre: Mercado Aberto, 1995.

FURTADO, F. Argumentos para a reabilitação do IPTU e do ITBI como instrumento de intervenção urbana (progressista), Revista Espaço e Debates, ano XVI, n.39, 1996.

SOUZA, Marcelo Lopes de. Problemas da Regularização Fundiária em Favelas Territorializadas por Traficantes de Drogas. In: ALFONSIN, Betânia; FERNANDE, 2004.

TEZANOS, J. F. La Exclusión. Madrid: [s.n.], 1999.

VALLADARES, Lícia do Prado. Favela, política e conjunto residencial. In: BLAY, Eva Alterman et al. A luta pelo espaço: textos de sociologia urbana. Petrópolis: Vozes, 1978.

Passa-se uma casa: análise do programa de remoção de favelas do Rio de Janeiro. Rio de Janeiro: Zahar, 1978.

VELHO, Gilberto. Uma bomba-relógio. O Globo, Rio de Janeiro, 07 out. 2003, p. 17.

VENTURA, Zuenir. Cidade partida. São Paulo: Cia das Letras, 2003.

VILLA, Fernando Gil. La exclusión social. Barcelona: Ariel, 2002.

VIOLÊNCIA DE VOLTA À FAIXA DE GAZA. O Globo, Rio de Janeiro, 25 mai. 2005, p. 16.

XIBERRAS, Martine. As teorias da exclusão: para uma construção do imaginário do desvio. Trad. José Gabriel Rego. Lisboa: Piaget, 1996.

WANDERLEY, Luiz Eduardo W. A questão social no contexto da globalização: o caso latino-americano e o caribenho. In: CASTEL, Robert; BELFIORE-WANDERLEY, Mariangela; Desigualdade e a questão social. 3.ed. São Paulo: EDUC, 2010.

WEBER, Max. Ensaios de sociologia. Trad. Waltensir Dutra. Rio de Janeiro: Zahar, 1963.

WOLFE, Marshall. Globalization and social exclusion: some paradoxes. In: ROGERS, Gary; GORE, Charles \& FIGUEIREDO, José (Orgs). Social exclusion: rethorie, reality, reposnes. Genebra: International Institute for Labor Studies, 1995.

Trabalho enviado em 29 de abril de 2015.

Aceito em 14 de julho de 2015. 